\title{
MARCAS Y EPÍGRAFES SOBRE ÁNFORAS DE ÉPOCA IBÉRICA. II
}

\author{
MARKS AND EPIGRAPHS ON IBERIAN AMPHORAE. II
}

\author{
LUCÍA SORIA COMBADIERA \\ Universidad de Castilla-La Mancha
}

CONSUELO MATA PARREÑO

Universitat de València

En 1997 publicábamos el primer repertorio de marcas y epígrafes sobre ánforas y contenedores ibéricos que sirvió para llamar la atención sobre el importante volumen existente y la amplitud geográfica del fenómeno, sobre todo, en las ánforas. A pesar del tiempo transcurrido, no se ha avanzado demasiado a la hora de informar sobre este tipo de hallazgos por lo que su existencia y distribución sigue siendo dispar. Además, en ocasiones, no se indica si la marca es pre o postcocción (incisa o esgrafiada), cuántas marcas hay en un mismo recipiente, donde se ubican e, incluso, se puede señalar la existencia de las mismas pero sin reproducir su imagen o descripción.

En este segundo repertorio hemos decidido dejar al margen las marcas sobre tinajas y dolia pues tienen características propias tanto a nivel funcional como cronológico y geográfico. De éstas, hasta el momento, tenemos inventariadas 115 marcas de 29 yacimientos, mayoritariamente de los siglos II-I a. C. en Aragón, Cataluña y S. de Francia. Por el contrario, las marcas sobre ánfora tienen una dispersión más amplia por todo el ámbito ibérico incluso se han documentado en las islas Baleares (Fig. 1).

Las nuevas marcas y epígrafes sobre ánfora han supuesto un aumento significativo de los mismos con 48 yacimientos más y 126 marcas $^{1}$. La documentación que presentamos procede de publicaciones, de trabajo de campo propio y de la información proporcionada, desinteresadamente, por algunos colegas a los que, desde aquí, les agradecemos su colaboración ${ }^{2}$.

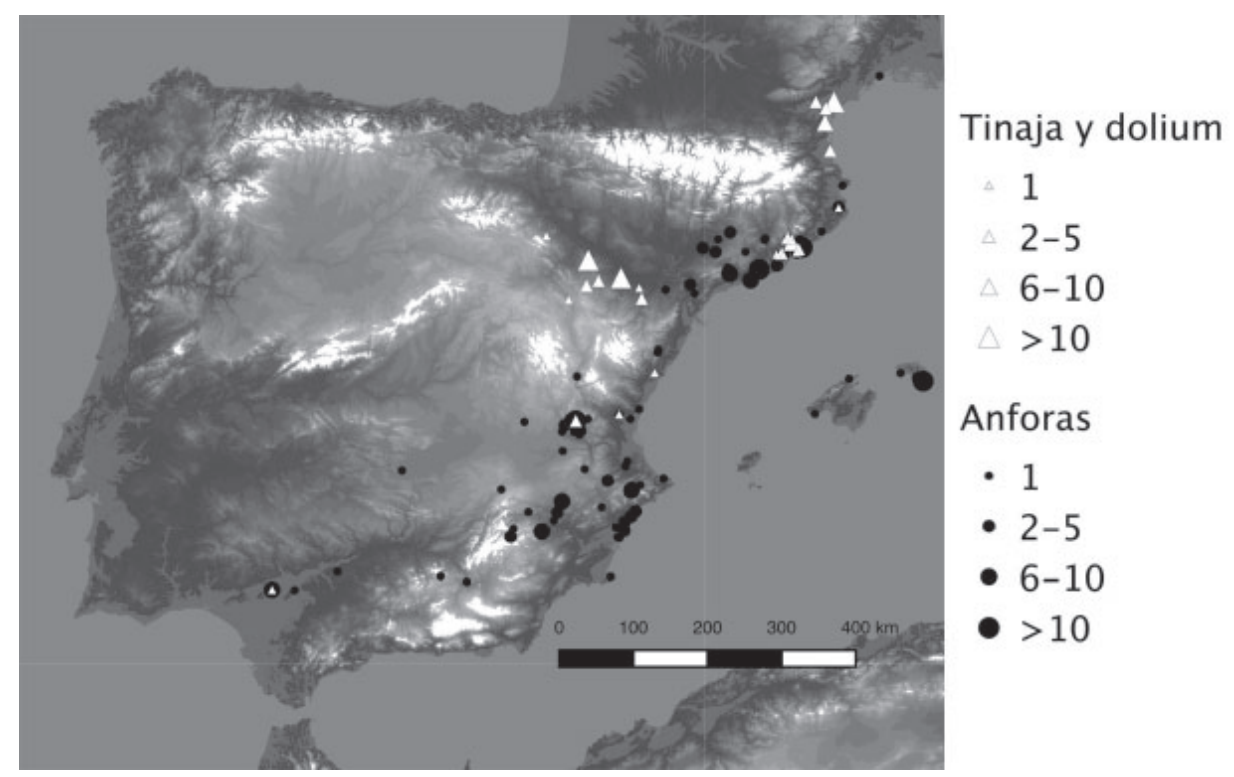

Figura 1: Distribución de marcas sobre ánforas, tinajas y dolia.

1. De un total de 263 marcas sobre ánfora.

2. Los mapas de distribución recogen la totalidad de las marcas conocidas por nosotras. 


\section{LAS ÁNFORAS}

Un modelo metodológico para aproximarse al conocimiento de la economía ibérica y de sus centros de producción y circuitos de intercambio es el estudio de las ánforas, su distribución, además del análisis del registro anepigráfico y epigráfico que éstas ofrecen. De ahí el interés de recopilar estas marcas siguiendo el ejemplo de otros ámbitos culturales contemporáneos (Callender, 1970; Calvet, 1982; Chic, 1985; Desy, 1989; Rodríguez Almeida, 1989; Carre et alii, 1995; Blanc-Bijon et alii, 1998; Garlan, 1999; Lawall, 2000; Remesal, 2004; además de los recientes recursos en red como http://projects.chass.utoronto.ca/cgi-bin/ amphoras/well, http://amphoralex.org, http://ceipac. gh.ub.es o http://amphorae.icac.cat, entre otros).

El estado de fragmentación en que se encuentran las ánforas ibéricas apenas permite identificar el subtipo, correspondiendo la mayor parte de los hallazgos a asas sueltas y galbos, aun así el subtipo de hombro redondeado es el predominante. Los ejemplares completos o con más de $2 / 3$ conservados de este subtipo son los de La Serreta (Fig. 11, 12005/6), Binisafúller (Fig. 10, 23032/3), El Puntal (Fig. 10, 52002), El Puig (Fig. 11, 55003/004), El Vilar (Fig. 15, 84006), Olèrdola (Fig. 15, 94013), Puig de Sant Andreu (Fig. 10, 45), Lucentum/Tossal de Manises (Fig. 11, 109002) y Tossal de les Basses (Fig. 11, 111001/3), mientras que las de hombro carenado sólo se han encontrado en Carmona (Fig. 8, 56001) y Alt de Benimaquia (Fig. 9, 71001).

Tampoco es posible saber con certeza el número de marcas por pieza, aunque lo habitual parece ser la presencia de una única marca. A las excepciones publicadas con anterioridad (Mata y Soria, 1997, fig. 9, 09.035; fig. 10, 09.057; fig. 11, 13.037 y 14.138), hay que sumar las de Can Vilà (Fig. 5, 75002), Rambla de la Alcantarilla (Fig. 6, 80001), Saiti (Fig. 7, 90001) y Olèrdola (Fig. 7, 94001).

\section{LOS YACIMIENTOS}

Las marcas se encuentran en asentamientos de diversa categoría y funcionalidad, incluso en hornos alfareros, silos y pecios. Presentaremos los yacimientos por provincias de sur a norte, siguiendo la numeración utilizada en el primer catálogo (Mata y Soria, 1997).

\section{Sevilla}

56. Carmona (Carmona). Carmona es una ciudad de situación estratégica entre la costa y el interior del valle del Guadalquivir. Las intervenciones arqueológicas de mediados de los años 80 han constatado una amplia cronología desde época tartésica hasta romana. De la casa-palacio del Marqués de Saltillo procede una marca anepigráfica e incisa sobre hombro (Fig. 8, 56001), datada en la segunda mitad del siglo V a. C. (Belén et alii, 1997, 84, fig. 9,1).

\section{Córdoba}

63. La Fuencubierta (La Carlota). Oppidum de 5 ha sobre un cerro aislado de notable altitud, en la campiña cordobesa. En este lugar se recogió una marca incisa y epigráfica (Fig. 12, 63001) sobre el hombro de un ánfora. Aunque descontextualizada se señala como posible cronología los siglos II-I a. C. (Martínez Castro y Tristell, 1999, 73-76; Martínez Castro, 2011, 137, fig. 4).

Jaén

115. El Pajarillo (Huelma). Monumento aristocrático del siglo IV a. C. del que se han publicado sus esculturas y algunos materiales cerámicos. Entre ellos, un ánfora con marca anepigráfica incisa en el borde (Fig. 9, 115001) (Molinos et alii, 1998, fig. 92, 68) .

\section{Ciudad Real}

99. Alarcos (Ciudad Real). Oppidum de unas 16-18 ha en época ibérica sobre un gran cerro en el valle medio del Guadiana. La cronología general del yacimiento va desde el siglo $\mathrm{V}$ al I a. C. Hemos incluido un letrero postcocción sobre el borde de lo que consideramos un ánfora (Fig. 14, 99001), de la campaña de 1986, aunque en la publicación no se especifica su tipología (Carrasco y Velaza, 2011, 228, 4).

\section{Albacete}

57. La Piedra de Peñarrubia (Elche de la Sierra). Oppidum de 6 ha sobre la plataforma superior de una gran muela amesetada, próximo al río Segura. En la parte oriental se conservan los restos de una imponente muralla que protege el flanco más accesible. La ocupación ibérica se inicia a finales del V a. C. llegando hasta época altoimperial (Soria, 2002, 138). En superficie se halló una marca incisa y epigráfica sobre un borde (Fig. 14, 57001).

107. El Tobar (Alcaraz). Pequeño establecimiento rural en piedemonte conocido mediante prospección ${ }^{4}$. Se ubica junto a dos veredas y cerca del río Horcajo. Durante las campañas de prospección se encontró una marca esgrafiada y epigráfica sobre galbo (Fig. 14, 107001).

\footnotetext{
3. Información y fotografía proporcionadas por el Instituto de Investigación en Arqueología Ibérica, Universidad de Jaén.

4. Carta Arqueológica del T.M. de Alcaraz, 2006.
} 


\section{Alicante}

12. La Serreta (Alcoi, Cocentaina, Penàguila). Conjunto arqueológico formado por un hábitat amurallado de 5,5 ha, santuario y necrópolis situado en una cima elevada. Tiene una amplia secuencia cronológica entre los siglos VI-II a. C. Las ánforas que presentamos aquí tienen marcas incisas sobre el hombro, fueron recogidas por Ribera (1982, 53, fig. 13-2, lám. VII, 1) (Fig. 11, 12005/6), y se añaden a las otras conocidas (Mata y Soria, 1997, 309).

52. El Puntal (Salinas). Asentamiento de tamaño medio de la primera mitad del siglo IV a. C. del que procede un ánfora casi completa con marca incisa en el hombro (Fig. 10, 52002) (Hernández Alcaraz y Sala, 1996, fig. 67, 3).

55. El Puig (Alcoi). Oppidum de 1,5 ha con un único acceso por el SO flanqueado por una sólida fortificación. La localización es ampliamente estratégica por su emplazamiento en un corredor natural. Su ocupación abarca desde el siglo VII al IV a. C. Cuatro de las marcas proceden de excavaciones antiguas y sólo una de las intervenciones recientes (Fig. 4, 55001; Fig. 10, 55002 y $55005 ; 11,55003 / 4$ ) (Ribera, 1982, 59, figs. 15, 23 y 17, 2; Grau et alii, 2012, 55, fig. 9, 480/89; Grau y Segura, 2013, 144, fig. 5.55-158/09).

62 y 97. Illeta dels Banyets (El Campello). Es un asentamiento situado en una estrecha península en el que se han identificado espacios públicos, religiosos, domésticos y varios lagares. En la zona periurbana se localiza un conjunto de hornos cerámicos. La fase ibérica se data desde el siglo V a. C. hasta mediados del III a. C. De los hornos procede una marca impresa y anepigráfica sobre asa (97001) de la que se desconoce su contexto y cronología, además de un número impreciso de ánforas con «una decoración peinada a la altura del hombro de la pieza» (López Seguí, 1997, 241, fig. 8, 2; López Seguí, 2000, 247) (Fig. 10, 97002). Del asentamiento se han publicado otras dos ánforas similares a éstas últimas (Fig. 10, 62001/2) (Álvarez, 1998, figs. 6, 3 y 8, 3).

67. La Picola (Santa Pola). Pequeño establecimiento de carácter portuario construido hacia 430 a. C. y abandonado al cabo de un siglo. Después de un largo periodo de abandono se reocupó a finales del siglo I a. C. A la primera fase corresponden dos marcas sobre galbo, epigráfica y anepigráfica (Fig. 16, 67001/2), de las que no se señala si son pre o postcocción (Badie $e t$ alii, 2000, fig. 72, 1 y 2).

71. L'Alt de Benimaquia (Dénia). Pequeño poblado de 0,5 ha localizado en una de las estribaciones del Montgó. Está delimitado en dos de sus lados por una muralla con seis torres. En su interior se han excavado varias estancias con lagares, de finales del siglo VII y el VI a. C. A pesar de la cantidad de ánforas descubiertas, tan solo se conoce una marca (Fig. 9, 71001) incisa y anepigráfica (Álvarez et alii, 2000, fig. 5-1).

108. Colmenares (Alacant). Pequeño asentamiento rural en llano y corta ocupación, desde finales del siglo V hasta la segunda mitad del IV a. C. Entre el abundante material anfórico registrado (71\%) destacan dos bordes y ocho fragmentos informes con incisiones en el hombro (108003; Fig. 10, 108001/2) (Moratalla y Segura, 2013, figs. 5, 11 y 14).

109. Lucentum/Tossal de Manises (Alacant). Situado sobre una elevación de $38 \mathrm{~m}$ snm próximo a una albufera. Muy bien emplazado para la defensa del territorio y el control visual de vías terrestres y marítimas, ha sufrido diversas interpretaciones en cuanto a su origen y cronología. La propuesta más reciente aboga por una fundación ex novo de carácter militar y origen bárquida en el último tercio del siglo III a. C., y una posterior ciudad romana, sin descartar la existencia anterior de un pequeño establecimiento ibérico (siglos IV-III a. C.). De este lugar se publicó un ánfora con incisiones sobre el hombro (Fig. 10, 109001) (Ribera, 1982, 71, fig. 32, 2; Olcina et alii, 2010).

111 y 116. Tossal de les Basses (Alacant). Conjunto arqueológico de poblado amurallado, área artesanal periurbana y fondeadero, próximo a Lucentum/Tossal de Manises. La ocupación protohistórica se inicia a finales del siglo VI y se abandona hacia el siglo I a. C., aunque perdura en época romana. Del área periurbana se han publicado tres ánforas con incisiones en el hombro y otra del poblado, todas fechadas en el siglo IV a. C. (Rosser, 2003, 81 y 142, fig. 68 2; Rosser y Fuentes, 2007, 108 y 109) (Fig. 11, 111001/3 y 116001) .

112. Benimassot (Benimassot). Pequeño hábitat en ladera y posible necrópolis datados en el siglo IV a. C. De aquí procede un ánfora con incisiones en el hombro (Fig. 10, 112001) (Grau, 2002, 310, fig. 100, 4).

Valencia

16. Kelin/Los Villares (Caudete de las Fuentes). En esta importante ciudad de amplia cronología se ha encontrado una marca más (Fig. 6, 16018) en el interior de un silo islámico que es igual a otras del mismo yacimiento (Mata y Soria, 1997, figs. 11, 16.003, 006 y 091; 13, 18.011; Quixal et alii, 2011, fig. 6).

17. Casillas del Cura (Venta del Moro). Centro alfarero de los siglos V-IV a. C. Se ha excavado uno de los hornos y se han estudiado las producciones más

5. Fotos proporcionadas por Pablo Rosser, jefe del Departamento de Patrimonio Cultural del Ayuntamiento de Alicante. 
significativas, entre ellas las ánforas. A las cuatro marcas ya conocidas, debemos añadir una más, también impresa sobre asa (Fig. 5, 17005) (Martínez Valle et alii, 2001; Martínez Valle y Hortelano, 2011; Martínez Valle, 2014, 63, fig. 19).

58. Covarrobles (Fuenterrobles). Establecimiento rural en llano con una amplia dispersión de materiales que ofrecen una cronología desde finales del siglo III a. C. hasta el I d. C. En este lugar se ha encontrado un asa con marca impresa y anepigráfica (Fig. 7, 58001) .

59. P.U.R.-2 (Villargordo del Cabriel). Establecimiento rural en llano cuya cronología se puede establecer por los materiales recuperados entre los siglos IV-III a. C. Durante la campaña de prospección de 1998 se encontró un asa con marca incisa en la parte superior del nervio (Fig. 9, 59001).

64. La Bastida de les Alcusses (Moixent). Asentamiento fortificado del siglo IV a. C. de más de 4 ha con un segundo recinto que amplía la superficie en 1,4 ha. Se está excavando, aunque de forma no continuada, desde 1928 (Bonet y Vives-Ferrándiz, 2011). Se han documentado dos marcas impresas y anepigráficas sobre sendas asas ${ }^{7}$ (Fig. 6, 64001/2), parecidas a otras del territorio de Kelin (Fig. 6).

70. La Atalaya (Caudete de las Fuentes). Estructuras dispersas periurbanas de carácter agrario o artesanal dependientes de Kelin. De las excavaciones de 1993 procede una marca impresa y anepigráfica sobre asa (Fig. 6, 70001), de diseño semejante a otras encontradas en Kelin y en otros asentamientos de su territorio (Mata y Soria, 1997, fig. 11, 16.003, 16.006 y 16.091; fig. 13, 18.011; Quixal et alii, 2011, 66, fig. 6, 6; Mata et alii, 2012, 189-190).

74. Tos Pelat (Moncada). Oppidum ibérico de unas 3 ha emplazado sobre una colina a unos $10 \mathrm{~km}$ de la costa actual. Las distintas intervenciones arqueológicas han sacado a la luz un conjunto de viviendas adosadas a la muralla, datado entre mediados del siglo VI y mediados del IV a.C. En la campaña de 2002 se documentó un asa con marca incisa y anepigráfica (Fig. 9, 74001) (Burriel y Mata, 2008 y 2103).

78. Los Terreros (Torrebaja). Yacimiento en ladera con unas 4 ha de dispersión de materiales, cerca de un paso natural. Su cronología abarca desde mediados del siglo VI hasta el siglo II a. C. De superficie procede

6. Yacimiento prospectado dentro del proyecto de investigación sobre el territorio de Kelin. Parte gráfica proporcionada por Fernando Moya, vecino de Fuenterrobles.

7. Parte gráfica e información facilitada por Jaime Vives-Ferrándiz y Helena Bonet, co-directores de las excavaciones. una marca esgrafiada y epigráfica sobre asa (Fig. 14, 78001) (Pérez Verbena, 2004, 134, fig. 3, 49).

80. Rambla de la Alcantarilla (Requena). Bodega de unos $150 \mathrm{~m}^{2}$ junto a dos lagares rupestres situados en el margen derecho de la rambla que le da nombre. En superficie se halló una marca doble impresa y anepigráfica sobre el nervio de un asa (Fig. 6, 80001) ${ }^{8}$. La excavación proporcionó una datación entre los siglos V y III a. C. (Mata et alii, 2009, 145; Quixal et alii, 2011, 64, fig. 6,7).

82. Casa de la Alcantarilla (Requena). Asentamiento rural en la ladera derecha de la rambla de la Alcantarilla, con una amplia dispersión de materiales que abarcan desde el siglo VI al I d. C. En superficie se recogió una marca impresa y anepigráfica sobre asa (Fig. 5, 82001) (Mata et alii, 2009, 145).

87. La Tejería (Fuenterrobles). Pequeño asentamiento situado en la ladera de una loma. Los materiales recogidos en las prospecciones de 1993 aportan una cronología desde el siglo II a. C. hasta el II d. C. En este lugar se halló una marca impresa y anepigráfica sobre un asa (Fig. 5, 87001) .

89. El Zoquete (Requena). Granja de 0,5 ha excavada en 2007 y 2008. Los materiales proporcionan una cronología desde el siglo V al III a. C. En uno de los departamentos se encontró una marca impresa anepigráfica sobre asa (Fig. 4, 89001) (Pérez Jordà et alii, 2007; Quixal et alii, 2008).

90. Saiti (Xàtiva). La antigua Saiti se localiza en la ladera sur-suroeste del Castell de Xàtiva con una superficie de unas 8 ha. Presenta indicios de ocupación desde el siglo VIII a. C. al III a. C. En niveles superficiales de la campaña de 2007 se recogió una marca impresa sobre hombro (Fig. 7, 90001) (Pérez Ballester et alii, 2007, 2008, 2011 y 2013 $)^{10}$.

\section{Cuenca}

79. Camino de las Casas del Rincón de Ramo (Iniesta). Asentamiento rural de 1 ha localizado en 2004, durante una campaña de prospección. Se ubica en una ladera baja en el margen derecho del río Cabriel. Los materiales aportan una fecha general entre los siglos V-III a. C. Se recogió una marca impresa y anepigráfica sobre asa (Fig. 5, 79001).

8. Material proporcionado por Vicente Sáez, antiguo propietario de la parcela.

9. Yacimiento prospectado dentro del proyecto de investigación sobre el territorio de Kelin. Fotografía proporcionada por Fernando Moya, vecino de Fuenterrobles.

10. Información y documentación proporcionada por José Pérez Ballester. 


\section{Mallorca}

92. Cala Sant Vicenç (Pollença). Barco mercante que transportaba un número importante de ánforas ibéricas, excavado entre 2003 y 2004. Del pecio se conoce una marca incisa y anepigráfica sobre el tercio superior de un ánfora ibérica datada entre 520-500 a. C. (Fig. 9, 92001) (Nieto y Santos, 2009, 181, fig. 153).

114. Puig sa Morisca (Calvià). Asentamiento talayótico cerca de la costa donde se recuperó, entre otros, un ánfora ibérica con marcas incisas en el hombro en un contexto del siglo IV a. C. (Fig. 10, 114001) (Guerrero y Quintana, 2000, 162, fig. 12).

\section{Menorca}

23. Binisafúller (Sant Lluís). De este pecio proceden once nuevas marcas incisas (Fig. 8, 23023/4, 23026/7 y 23029; Fig. 9, 23025; Fig. 10, 23032/3; Fig. 12, $23028,23030 / 1)$. El total asciende ya a 33 aunque no descartamos que su número aumente en el futuro con la continuidad de los trabajos de excavación. La mayoría son signos anepigráficos, aunque algunos están incompletos, y sólo tres de los nuevos se pueden considerar, con cierta seguridad, como epigráficos (Guerrero y Quintana, 2000, fig. 7, 40 y 41; Aguelo y Pons, 2011, 99; Aguelo et alii, 2013, 72-74) $)^{11}$. Las excavaciones más recientes han documentado una cantidad considerable de pepitas de uva, algunas de ellas de vid silvestre, asociadas a estas ánforas (Aguelo et alii, 2013, 74-75).

69. Son Catlar (Ciutadella). Poblado talayótico de 3,75 ha, con niveles de ocupación en la Edad del Hierro. Ha sido objeto de varias campañas de excavación $\mathrm{y}$ de superficie se ha recogido una marca impresa y anepigráfica $^{12}$ sobre hombro (Fig. 7, 69001).

113. Cales Coves (Alaior). Fondeadero en una cala al sur de Menorca en cuyas aguas se ha recuperado un ánfora con incisiones sobre el hombro (Fig. 10, 113001) (Guerrero y Quintana, 2000, 172, fig. 9, 50).

\section{Tarragona}

24. Alorda Park (Calafell). Pequeño poblado fortificado de unos $1800 \mathrm{~m}^{2}$ de superficie sobre un cerro próximo a la costa que disponía de un pequeño embarcadero. Presenta varias fases de ocupación desde el siglo VI al II a. C. En la publicación de 1997 (Mata y

11. Información y material gráfico proporcionado por Xavier Aguelo, co-director de las excavaciones de Binisafúller.

12. Parte gráfica e información facilitada por Joan de Nicolás de l'Institut Menorquí d'Estudis.
Soria, 1997, fig. 15, 24.055) se catalogó una marca, a la que con posterioridad se han sumado seis más. Todas son anepigráficas pero las hay pre y postcocción, impresa, a carbón y con pintura roja (24006; Fig. 4, 24007; Fig. 7, 24002; Fig. 15, 24003/5) (Sanmartí et alii, 1998, figs. 10, 5; 14, 3-6).

60. Castellet de Banyoles (Tivissa). Asentamiento de 4,5 ha situado sobre una plataforma de laderas abruptas en el margen izquierdo del río Ebro. Los trabajos realizados desde 1998 han puesto al descubierto un sector de viviendas y un santuario ocupados entre el último tercio del siglo III a. C. y principios del II a. C. De este yacimiento procede una marca epigráfica sobre asa, incisa o esgrafiada, pues no se ha publicado una imagen de la misma (60001) (Sanmartí et alii, 1998, 282; Sanmartí et alii, 2012).

61. Tossal del Moro de Pinyeres (Batea). Poblado situado en una colina en el margen izquierdo del río Algars. La primera ocupación se data entre mediados del siglo VII y el primer tercio del siglo VI a. C. Tras un hiatus de casi un siglo, fue reocupado durante los siglos V y IV a. C. de donde procede una marca impresa y anepigráfica sobre asa (Fig. 7, 61001) (Pérez Suñé y Revilla, 1999, fig. 2, 11). En la base de la ladera sur se documentó en 1982 un horno cerámico (Arteaga et alii, 1990, 57).

83. Sant Miquel (Vinebre). Establecimiento fortificado sobre un cerro en la ribera izquierda del Ebro. Se habita desde el último cuarto del siglo II a. C. hasta finales del I a. C. En la campaña de 1992 se halló una marca incisa y epigráfica sobre borde (83001) (Genera, 2005, SM 92.33.1.93, 1001, fig. 3), datada a finales del siglo II a. C.; del mismo yacimiento también procede otro epígrafe sobre galbo (83002), que no se reproduce y del que tampoco se indica si es inciso o esgrafiado (Genera, 2005, 1001 y 1002, fig. 3).

84. EI Vilar (Valls). Asentamiento de 6 ha sobre una suave elevación cerca de la ciudad de Valls, por lo que se encuentra muy afectado por diversas construcciones urbanas. Se han catalogado ocho marcas, de las que cinco son impresas y tres trazadas con carbón (Fig. 5, 84001 y $84004 / 5$; Fig. 7, 84002/3; Fig. 15, 84006/8) (Otiña y Vergès, 2004, fig. 2, 11; Fabra y Vilalta, 2008, 189, figs. 103, 1-3 y 104, 3; Fabra et alii, 2013, 247249, figs. 2-4) $)^{13}$.

91. Fontscaldes (Valls). Yacimiento con un horno excavado y diversos testares cuya cronología se ha establecido en el siglo II a. C. De uno de los testares proceden dos marcas sobre ánfora, una pintada epigráfica y la otra anepigráfica realizada con carbón (Fig. 15,

13. Parte gráfica facilitada por Ester Fabra del Institut d'Estudis Vallencs. 
91001/2) (Solé, 2008, 309, figs. 190, 3 y 191, 1; Fabra et alii, 2013 $)^{14}$.

\section{Barcelona}

29. Turó de Ca n'Olivé (Cerdanyola del Vallès). Asentamiento de prolongada ocupación desde el último cuarto del siglo VI a. C. hasta el 75-50 a. C. De este lugar se publicó una marca epigráfica (Mata y Soria, 1997, fig. 16, 29.106) a la que se añaden otras dos, igualmente esgrafiadas y epigráficas (Fig. 14, 29002/3) (Francès et alii, 2008, 221 y 225, figs. 4 y 17).

30. Camí de Vista Alegre (Mataró). Vertedero con abundantes restos de ánforas, algunas con defectos de cocción. A las marcas ya publicadas hemos de añadir un ánfora con incisiones en el hombro de la primera mitad del siglo III a. C. (Fig. 11, 30006) (AA.VV., 1995, fig. 20, 3; Mata y Soria, 1997, 312). Este yacimiento, asociado a hornos cerámicos, es uno de los que tiene mayor número de marcas.

75. Can Vilà (Premià de Dalt). Asentamiento en llano de la comarca del Maresme en el que se ha documentado un horno cerámico. Se ocupa desde finales del siglo IV a. C. hasta la segunda mitad del siglo II a. C. De él proceden una marca incisa y epigráfica sobre galbo (Fig. 12, 75001) y otra impresa sobre borde (Fig. 5, 75002) (Coll et alii, 2002, figs. 6, 23 y 12, 127).

94. Olèrdola (Olèrdola). Oppidum ibérico situado en un altozano que vigila la llanura del Penedès. De extensión considerable, jugó un destacado papel dentro del territorio cesetano desde la segunda mitad del siglo $\mathrm{V}$ a. C. De época ibérica se conservan la muralla, espacios domésticos, un complejo artesanal de tintes y un taller metalúrgico. A principios del siglo I a. C. los romanos establecieron un campamento militar en la zona. En el yacimiento se han encontrado 16 marcas sobre ánfora, de las que 10 (Fig. 4, 94005/11; Fig. 7, 94001/3) son impresas y anepigráficas, tres incisas y anepigráficas (Fig. 8, 94015/16; Fig. 9, 94004), dos incisas y epigráficas (Fig. 12, 94012 y 94014) y una marca pintada anepigráfica (Fig. 15, 94013). Casi todas ellas se fechan entre los siglos II y I a. C. (Molist, 2009, figs. 11.43 y 11.44).

\section{Lleida}

86. Tossal de les Tenalles (Sidamon). Poblado de pequeñas dimensiones situado sobre una suave elevación. Las excavaciones realizadas han aportado abundante material de importación que permite fechar su

14. Parte gráfica facilitada por Ester Fabra del Institut d'Estudis Vallencs. ocupación entre los siglos IV y I a. C. De este yacimiento proceden tres marcas descontextualizadas una impresa, otra incisa y, la tercera, incisa o esgrafiada (Fig. 5, 86003; Fig. 12, 86001; Fig. 16, 86002) (Barberá, 1964-1965; Garcés Estallo y Pérez Conill, 2006; Pérez i Conill, sin año, 101, lám. 7-4, 126, lám. 33-1 y 127 lám. 34-1).

96. La Fogonussa (Sant Martí de Riucorb). Poblado en el extremo occidental de un cerro en las proximidades del río Cuervo con gran control visual. En superficie se han recogido cinco marcas, tres de ellas impresas anepigráficas (Fig. 5, 96001/3) y otras dos incisas y epigráficas (Fig. 12, 96004/5). Por los materiales conocidos se datan entre los siglos IV-II a. C. (Garcés y Torres, 2011, 49-50, figs. 3, 2 y 3; 4, 4-8).

98. Molí d'Espígol (Tornabous). Poblado amurallado de 1 ha en el límite nororiental de la llanura de Urgell. Estuvo habitado desde finales del siglo VII hasta el siglo I a. C. Se ha catalogado una marca esgrafiada y epigráfica (Fig. 14, 98001) sobre asa, del siglo III a. C. (Cura, 2006, 139, lám. 28.5) ${ }^{15}$.

101. Iesso (Guissona). Fundación romana ex novo en el 100 a. C. con muralla perimetral, cuyos restos se conservan bajo la población actual de Guissona. Las excavaciones realizadas han exhumado abundantes materiales de importación itálica, si bien una parte de la cultura material refleja el peso de la cultura autóctona ibera. De este lugar se conoce un letrero impreso sobre asa de finales del siglo I a. C. (Fig. 5, 101002) (Pera, 2003, figs. 4, 30 y 6, 30; Guitart et alii, 2004).

\section{Zaragoza}

73. Contrebia Belaisca (Botorrita). Ciudad situada sobre un cerro en el margen derecho del río Huerva desde el que domina el área circundante. El momento de máximo esplendor tuvo lugar entre los siglos II-I a. C. aunque la fecha más antigua es el siglo V a. C. De un lote de 19 marcas, sólo una, epigráfica y esgrafiada (Fig. 14, 73013), ha sido plasmada sobre el galbo de un ánfora ibérica (Díaz y Jordán, 2001, fig. 20) mientras que el resto se realiza sobre dolia.

\section{Girona}

45. Puig de Sant Andreu (Ullastret). Ciudad ibérica también de amplia cronología en la que se sigue excavando. Recogemos cuatro ánforas con incisiones en el hombro del sigo IV a. C. de las excavaciones de M. Oliva de 1949 y otra impresa de 1971-1972, estrato

15. Aunque en la publicación no se señala si es incisa o esgrafiada, Jordi Principal nos pudo confirmar que era postcocción. 
III, Dep. i (MAC-Ullastret, inv. 3500) ${ }^{16}$ (Fig. 5, 45005; Fig. 11, 45006/9) (Sanmartí y Bruguera, 1998, 191, figs. 10 y 11).

46. Illa d'en Reixac (Ullastret). Asentamiento en llano situado en las proximidades del anterior y con una cronología similar. De él se ha publicado una nueva marca incisa sobre asa (Fig. 12, 46002) (Martín et alii, 1999, fig. 9.5, 13).

93. Rhode (Roses). La colonia griega de Rhode se fundó entre fines del siglo $\mathrm{V}$ y principios del IV a. C. sobre una pequeña colina situada entre dos cursos de agua y muy cercana a un puerto natural. A fines del siglo IV a. C. el asentamiento se amplía con una zona cercana al puerto, conocida como barrio helenístico, del que procede una marca impresa sobre asa de ánfora ibérica (Fig. 7, 93001) (Puig y Martín, 2006, 187, fig. $6,4,5)$.

100. Camp d'en Gou-Gorg d'en Batlle (Ullastret). Pequeño establecimiento en las proximidades del Puig de Sant Andreu e Illa d'en Reixac, interpretado como un barrio periurbano de carácter artesanal del oppidum que incluye restos de un horno cerámico. Ofrece una cronología de mediados del siglo IV e inicios del siglo II a. C. En una de las estancias se halló una marca impresa y anepigráfica sobre asa (Fig. 7, 100001) fechada en la segunda mitad del siglo III a. C. (Martín et alii, 2008, 179, fig. 11.4).

104. Montbarbat (Lloret de Mar). Poblado fortificado de 0,5 ha sobre la cima de una montaña con amplio control visual. Se habita entre el segundo cuarto del siglo IV y principios del siglo III a. C. De aquí procede una marca anepigráfica, incisa o esgrafiada, sobre el nervio de un asa (Fig. 16, 104001) (Pujol, 1989, 136, lám. 225).

\section{Francia}

68. Lattara (Lattes). Asentamiento situado en la desembocadura del Lez, con una superficie de 9 ha. Los trabajos de prospección y excavación desarrollados durante casi 30 años han evidenciado que constituyó un enclave comercial portuario del Mediterráneo entre los siglos VII a.C. y II d.C. De él se ha publicado una marca incisa o esgrafiada sobre hombro (Fig. 16, 68001) datada entre 300/100 a. C. (Py et alii, 2001, A-IB S4, no 387).

95. Pech Maho (Sigean). Emporio situado a $10 \mathrm{~km}$ del golfo de León, sobre una pequeña colina. La cronología del lugar se ha establecido entre mediados del siglo VI y finales del III a. C. De un total de 11 marcas publicadas, hay sólo una esgrafiada y epigráfica sobre galbo de ánfora ibérica (Fig. 14, 95011). Se fecha entre finales del siglo VI y mediados del V a. C. (Gailledrat y Solier, 2004, 348-348, fig. 279, 4).

\section{LAS MARCAS}

Para el análisis de las marcas seguiremos el mismo esquema que en el trabajo anterior (Mata y Soria, 1997), es decir, distinguiremos las diferentes técnicas de elaboración, sus tipos y clases. Estas últimas pueden ser anepigráficas y epigráficas, compuestas tanto por una como por varias letras. A las técnicas ya conocidas -impresa, incisa, esgrafiada-, se han añadido las realizadas con carbón y las pintadas, ambas postcocción.

Como hemos señalado al principio la cantidad de marcas se ha ampliado considerablemente, sobre todo, las impresas, aunque ello no siempre va acompañado de una mayor repetición de motivos, ni de una mejor identificación de la tipología de las ánforas (Fig. 2).

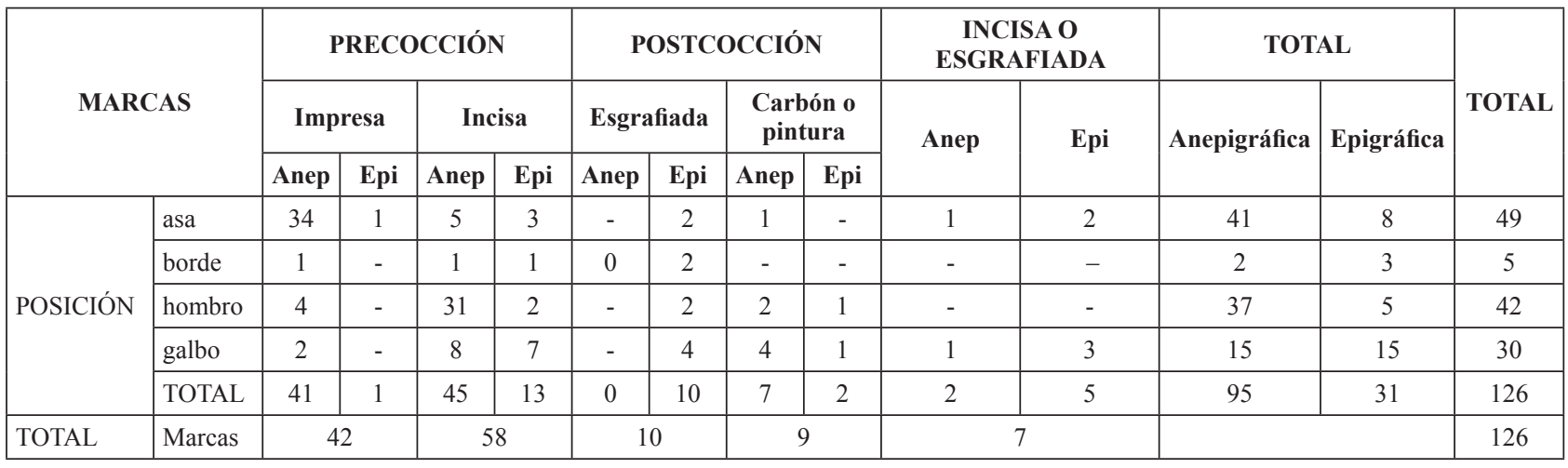

Figura 2: Cuadro-resumen de las nuevas marcas sobre ánfora.

16. Información y material gráfico proporcionados por Gabriel de Prado Cordero, Arqueólogo responsable del MAC-Ullastret. 


\subsection{MARCAS PRECOCCIÓN}

Las marcas precocción se realizan con la arcilla aún blanda y constituyen un eslabón más en el proceso de producción, lo que en principio señala al alfarero como autor de las mismas. La variedad de diseños detectados nos reafirma en descartar que se trate de marcas de taller (Mata y Soria, 1997, 350), incluso las asociadas a hornos cerámicos -Cerro Macareno, Casillas del Cura, Can Vilà, Boades, Camí de Vista Alegre, Tossal del Moro de Pinyeres, Can Badell o Vedell, Fontscaldes y Camp d'En Gou-Gorg d'en Batlle-, con la excepción de Illeta dels Banyets y Tossal de les Basses. Son las marcas más numerosas, incluso en los yacimientos de las islas Baleares (Figs. 2 y 3 ).

Las técnicas detectadas son la impresión y la incisión, ambas pueden ser anepigráficas, siempre más numerosas, y epigráficas. Hemos contabilizado un total de 95 marcas en 38 yacimientos nuevos y en nueve de los ya conocidos (La Serreta, El Puntal, Kelin, Casillas del Cura, Alorda Park, Camí de Vista Alegre, Puig de Sant Andreu, Illa d'en Reixac y Binisafúller) (Fig. 2). A estas cifras cabría la posibilidad de añadir otros cinco yacimientos (La Picola, Castellet de Banyoles, Sant Miquel, Tossal de les Tenalles, Montbarbat y Lattara) con marcas catalogadas como incisas/esgrafiadas pues en las publicaciones no se especifica la técnica de realización y no hemos tenido ocasión de examinarlas directamente (Fig. 16).

\subsubsection{Marcas impresas}

Estas marcas se encuentran en 25 yacimientos, con concentraciones significativas en el País Valenciano y
Cataluña (Fig. 3). El marco temporal abarca todo el periodo ibérico desde el siglo V a. C. en El Puig (Fig. 4, 55001) y Casillas del Cura (Fig. 5, 17005), hasta mediados del siglo I a. C. en Olèrdola (Fig. 4, 94006/94010), si bien son más frecuentes entre los siglos IV y II a. C.

Las impresiones pueden ser simples si la marca ha sido realizada con un utensilio que deja su impronta y sin un motivo interior; o complejas, es decir, un sello o estampilla con un motivo o un letrero grabado en positivo o en negativo. De ambas impresiones la más frecuente sigue siendo la compleja. Frente a la variedad de marcos identificados en la publicación anterior, ahora sólo se han documentado el cuadrangular (A) y el oval o circular (B). Excepcionales siguen siendo los sellos con motivos figurativos. A los ya publicados de El Macalón y La Serreta (Mata y Soria, 1997, 326 fig. 8, 07.021 y 331, fig. 10, 12.110, respectivamente), hay que añadir los del Vilar y La Fogonussa (Fig. 5, 84001 y 96001).

\subsubsection{Impresas Anepigráficas}

Se ubican preferentemente sobre las asas, en el arranque superior, en el nervio y, en ocasiones, en la parte inferior (Fig. 2). Se han localizado en yacimientos de las actuales provincias de Valencia y Alicante y en la costa de Cataluña; en Camino de las Casas del Rincón del Ramo (Fig. 5, 79001), limítrofe con la comarca valenciana de Requena-Utiel y en Son Catlar (Fig. 7, 69001), fruto de la actividad comercial (Fig. 3).

Los diseños identificados son ${ }^{17}$ :

Enmarque cuadrangular con motivo longitudinal (AI): Este enmarque que no es muy abundante en las

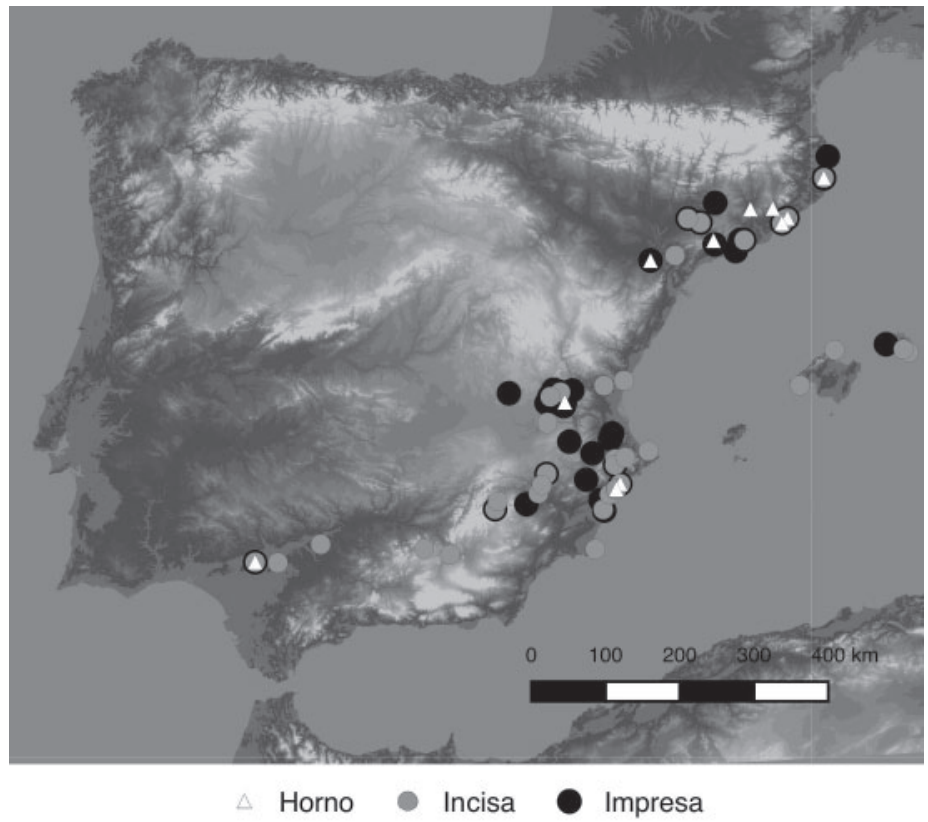

Figura 3: Distribución de todas las marcas precocción conocidas sobre ánfora.

17. Seguimos la misma clasificación utilizada en 1997, basada en el artículo de Ruiz Rodríguez y Nocete, 1981. 
ánforas se ha encontrado en el arranque de un asa de Casa de la Alcantarilla (Fig. 5, 82001). Dentro de una cartela cuadrada hay dos triángulos enfrentados por la base y uno de ellos con la bisectriz indicada. A pesar de la amplia cronología de este yacimiento, se puede afirmar que el ánfora es ibérica y, por tanto, enmarcada entre los siglos V y II a. C.

Enmarque oval o circular (B): El diseño más sencillo es una impresión realizada con un instrumento de punta roma sobre el nervio o en el arranque superior del asa (Fig. 4). Se han encontrado en Olèrdola (94005/9), Alorda Park (24007) y El Zoquete (89001); de forma excepcional, en un ánfora de Olèrdola, la impresión se sitúa en el galbo por debajo del asa (94010). Otro motivo simple está hecho con un cilindro hueco sobre el arranque superior del asa, en sendas de Olèrdola y de El Puig (Fig. 4, 94011 y 55001).

Enmarque oval o circular con motivo longitudinal $(B-I)$ : Documentado en nueve ánforas en las que se pueden ver al menos tres diseños diferentes. El primero de ellos, consiste en ocho o seis puntos impresos en negativo dentro del enmarque circular u oval en el nervio o en el arranque del asa (Fig. 6). A los ya conocidos (Mata y Soria, 1997, 323), hay que sumar nuevos ejemplares en Kelin (16018), La Atalaya (70001), Rambla de la Alcantarilla (80001) y La Bastida de les Alcusses (64001/2). El asa de Rambla de la Alcantarilla tiene la peculiaridad de presentar dos impresiones iguales sobre la misma. La cronología más segura la proporciona La Bastida de les Alcusses (siglo IV a. C.), pues todas las demás están descontextualizadas.

El segundo diseño consiste en un trazo longitudinal atravesado por otros dos transversales (Fig. 5) y se ha documentado en El Vilar (84004), en el Tossal de les Tenalles (86003) y, probablemente, en Puig de Sant Andreu (45005). En este último caso, los trazos transversales parecen converger, lo que puede ser tanto un defecto de la impresión como un motivo diferente. La fecha más precisa es la del Puig de Sant Andreu (siglo III a. C.), oscilando las demás entre los siglos IV-II a. C.

El tercer diseño (Fig. 5), sobre un asa de El Vilar (84005) y un borde de Can Vilà (75002), representa una herbácea con hojas alargadas a lo largo de un eje longitudinal. La fecha más tardía se da en el horno de Can Vilà, entre los siglos II y I a. C.

Enmarque oval o circular con motivo radial (B-II): Al igual que en el catálogo anterior (Mata y Soria, 1997, 323), sigue siendo la marca más numerosa, documentándose en 14 ánforas y 11 yacimientos. Son más frecuentes entre los siglos IV y II a. C., aunque aparecen desde el siglo VI en El Macalón (Mata y Soria, 1997, 308, fig. 8, 07.030) y siguen realizándose en el siglo I a. C. (Olèrdola, Fig. 7, 94001, entre otros). Se han reconocido tres diseños, dos de ellos ya identificados (Mata y Soria, 1997, 323).
El más simple es una cruz o aspa en positivo, estampada de manera preferente en el asa (Fig. 7). Se ha encontrado en El Vilar (84002/3 y 84009), en Rhode (93001), Tossal del Moro de Pinyeres (61001), Covarrobles (58001), Olèrdola (94002/3) e Illeta dels Banyets (62001). Cronológicamente se enmarcan entre los siglos V-II a. C.

El segundo motivo consiste en varios radios en relieve a modo de flor esquemática en vista cenital o asterisco (Fig. 7). Cuatro están sobre el hombro (24002, 69001, 90001 y 94001) y sólo uno sobre asa (100001). Además, en las piezas de Olérdola (94001) y Saiti (90001) el motivo está repetido, circunstancia que también podría darse en Alorda Park y Son Catlar. El número de radios puede ser un elemento para agrupar sellos iguales ${ }^{18}$, aunque no siempre están completos. Las fechas oscilan entre la mitad del siglo III a. C. y el segundo cuarto del I a. C.

El último diseño se da únicamente en un asa de La Tejería (Fig. 5, 87001) y consiste en ángulos paralelos con el vértice hacia el interior.

Enmarque circular con motivo reticulado (B-III): El único ejemplar procede del horno de Casillas del Cura (Fig. 5, 17005) (Martínez Valle, 2014, fig. 63, fig. 19). En Castellar de Meca hay un diseño semejante, aunque en apariencia con muchos más trazos (Mata y Soria, 1997, fig. 11 14.038).

Enmarque oval o circular con motivo no representativo (B-VII): Hemos catalogado dentro de este tipo cuatro marcas sobre asa que albergan en su interior un motivo indefinido o incompleto (Fig. 5). Una de ellas del Camino de las Casas del Rincón Ramo (79001) recuerda por su enmarque a otras ya publicadas e incluso tiene cierto parecido con el pie impreso de El Moluengo (Mata y Soria, 1997, 329-330, fig. 10, 11.072, 12.109 y 12.186; fig. 13, 18.010); la de El Vilar (84001) tiene en su interior un motivo, en apariencia, figurativo pero se incluye aquí al no poder distinguir de qué se trata; y las dos de La Fogonussa (96002/3) pueden ser iguales, pero una de ellas está incompleta. Su localización geográfica es dispersa (Cuenca, Tarragona y Lleida) pero no ocurre lo mismo con la cronología que globalmente se sitúa siglos III-II a. C.

Enmarque circular con motivo figurativo (B-VIII): En el arranque superior de un asa de La Fogonussa (Fig. 5, 96001) se ha impreso una marca excepcional (Garcés y Torres, 2011, inv. 1160, fig. 4, 4 y 5). Está completa y en el interior de la matriz se ha representado un grifo en positivo. Realizado con gran precisión, aparece en posición ligeramente flexionada, destacándose las zarpas y con alas desplegadas. Se distingue la cabeza,

18. Los números más repetidos son 7 (2) y 8 (3). El ánfora de Saiti (Fig. 7, 90001) tiene unos 14 radios. 

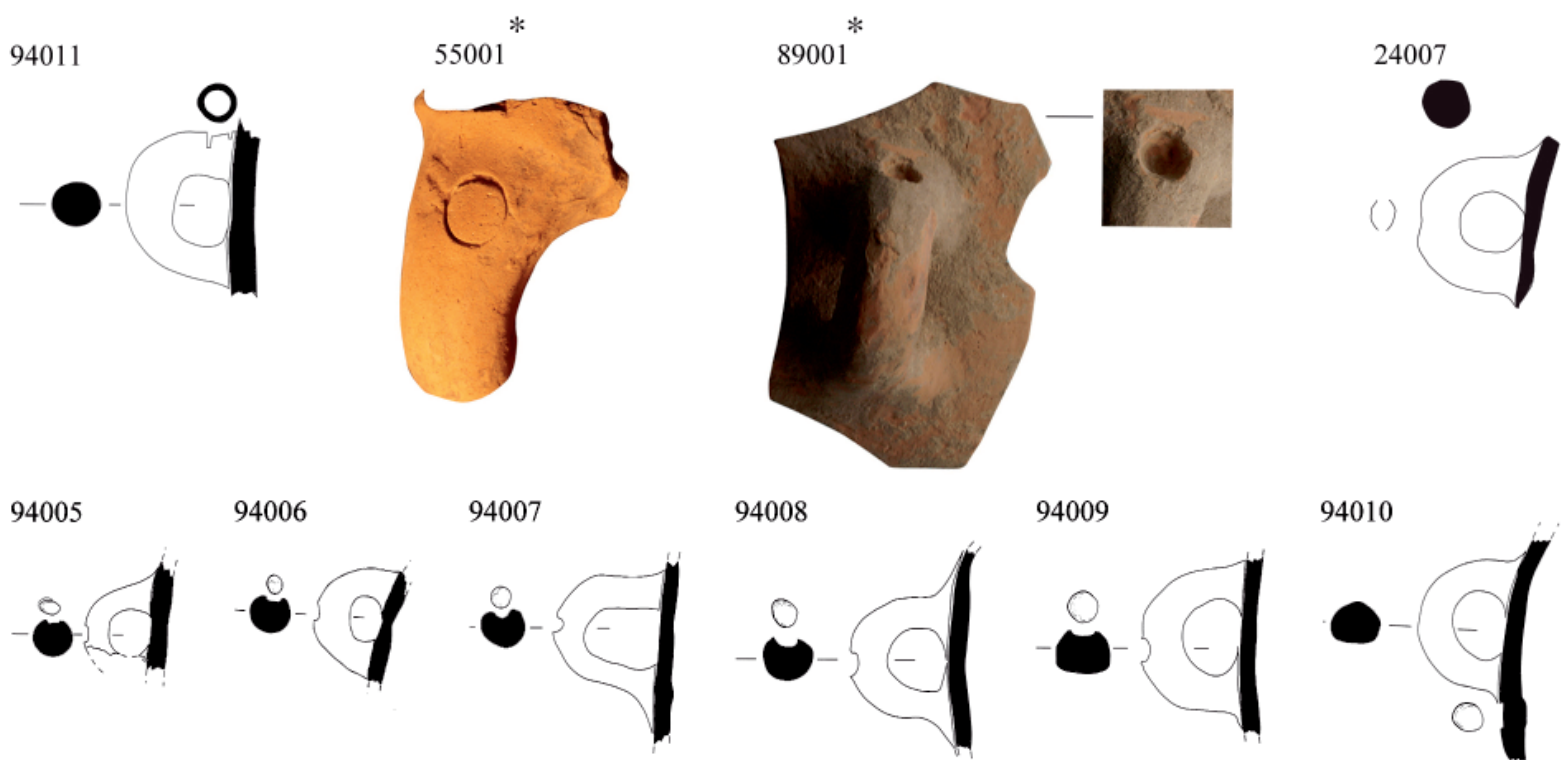

94009

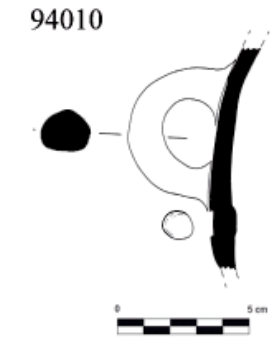

Figura 4: Impresiones circulares simples (B), anepigráficas (* sin escala): Olèrdola, 94005/11 (según Molist, 2009); El Puig, 55001; El Zoquete, 89001; Alorda Park, 24007 (según Sanmartí et alii, 1998).
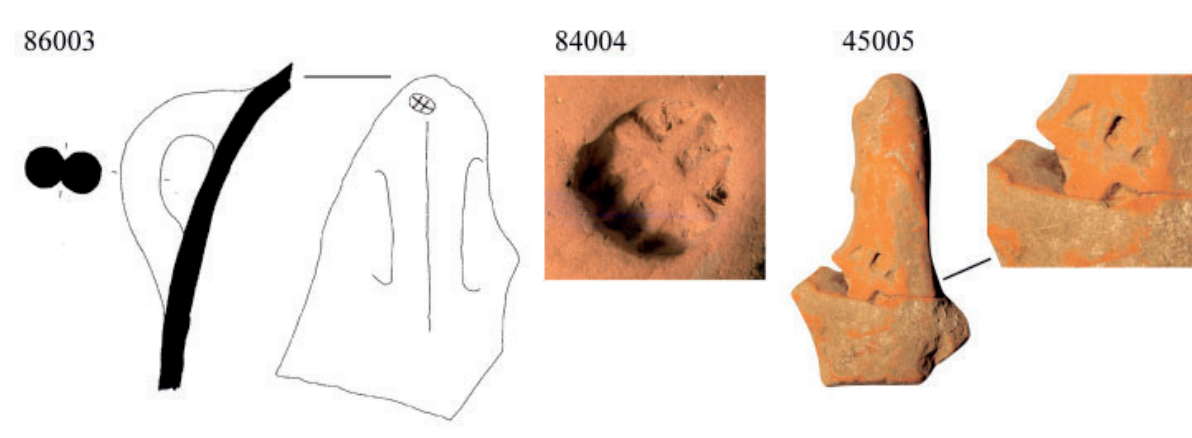

17005
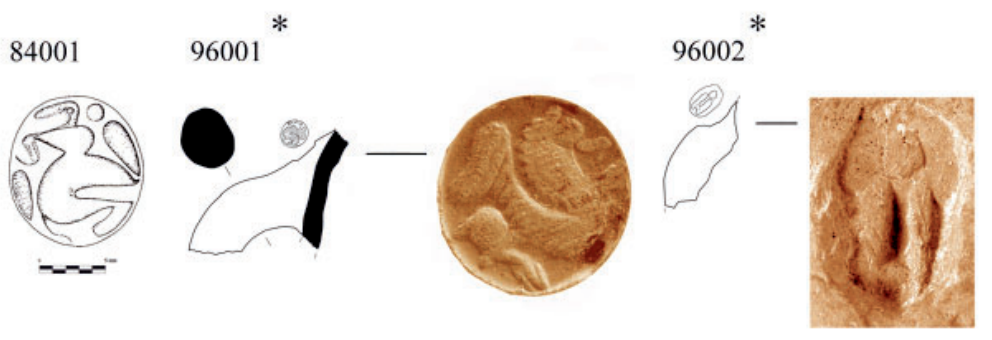

$96003 *$
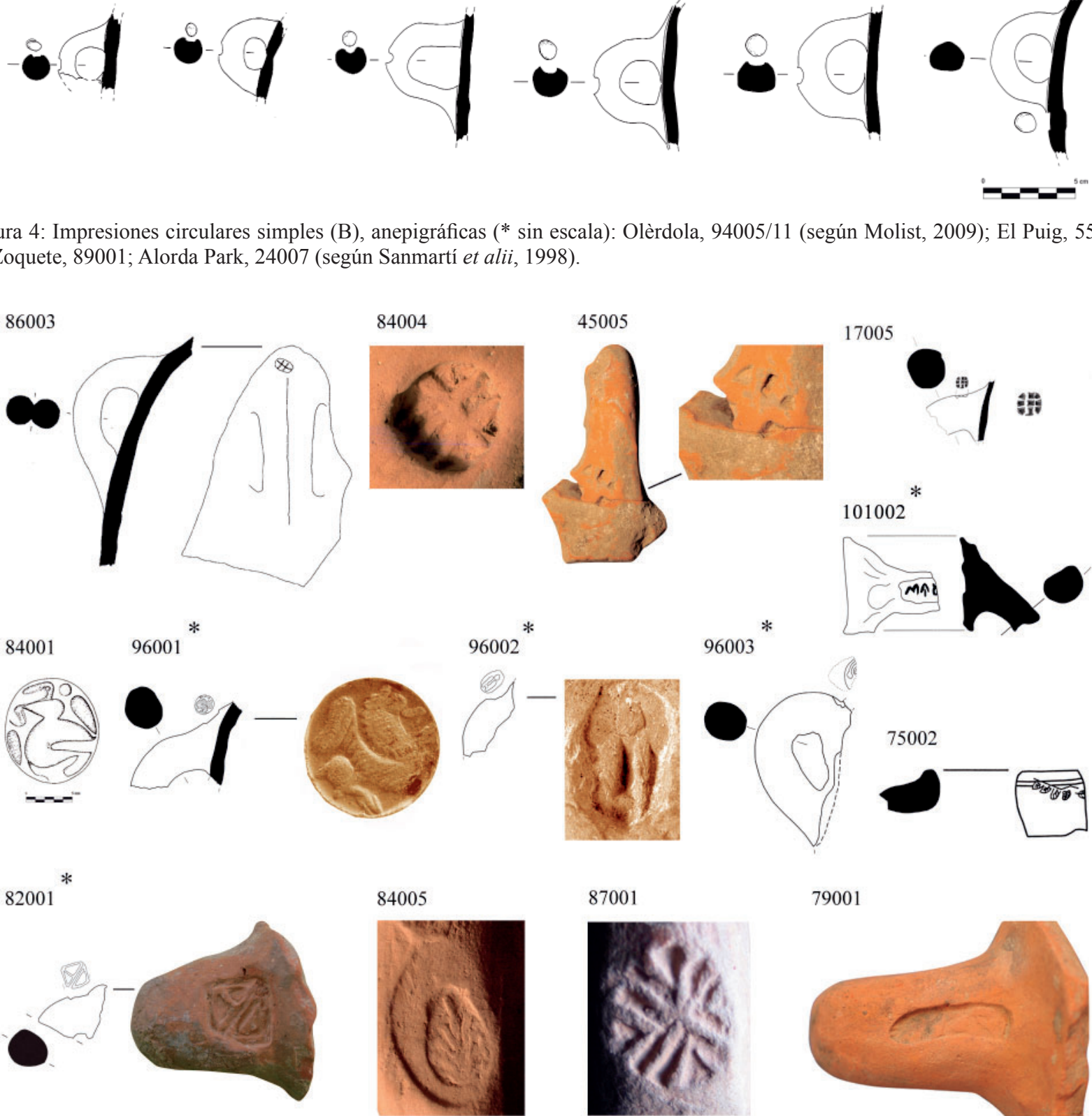

87001
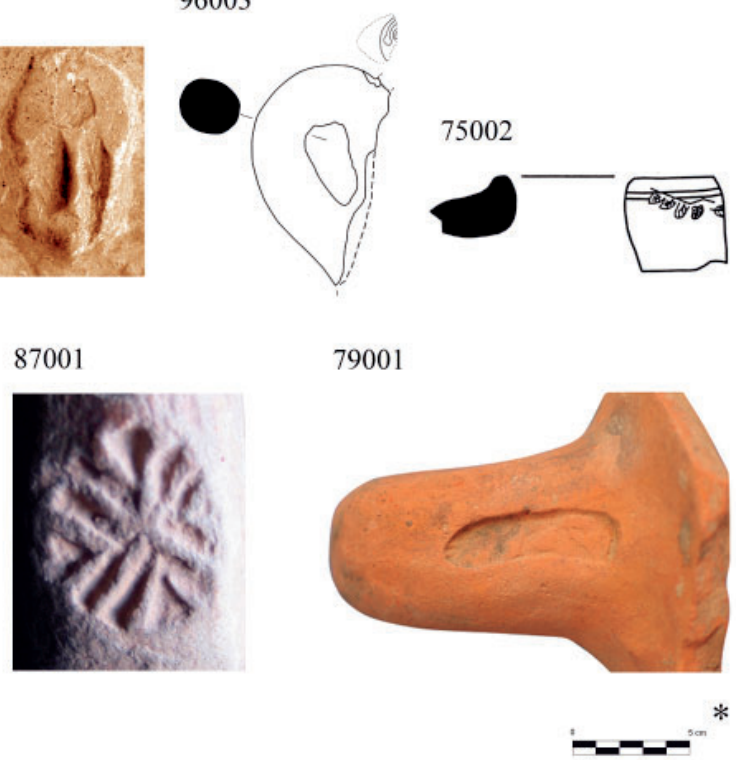

Figura 5: Impresiones con estampilla cuadrangular y oval o circular (A y B), epigráficas y anepigráficas (* con escala): Tossal de les Tenalles, 86003 (según Pérez i Conill); El Vilar, 84001 y 84004/5 (según Otiña y Vergès, 2004; Fabra et alii, 2008 y 2013); Puig de Sant Andreu, 45005 (fotografía MAC-Ullastret); Casillas del Cura, 17005 (según Martínez Valle, 2014); Iesso, 101002 (según Pera, 2003); La Fogonussa, 96001/3 (según Garcés y Torres, 2011); Casa de la Alcantarilla, 82001; Can Vilà, 75002 (Coll et alii, 2002); Camino de las Casas del Rincón del Ramo, 79001; La Tejería, 87001 (fotografía F. Moya). 


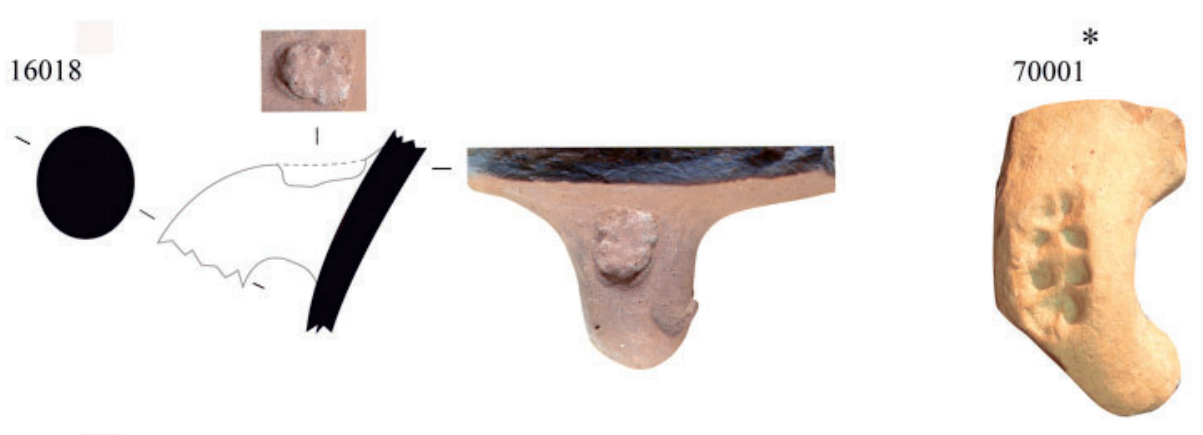

64002

64001
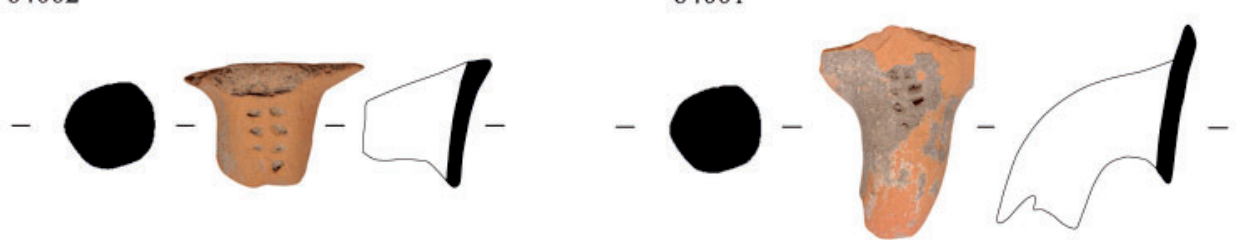

*

80001
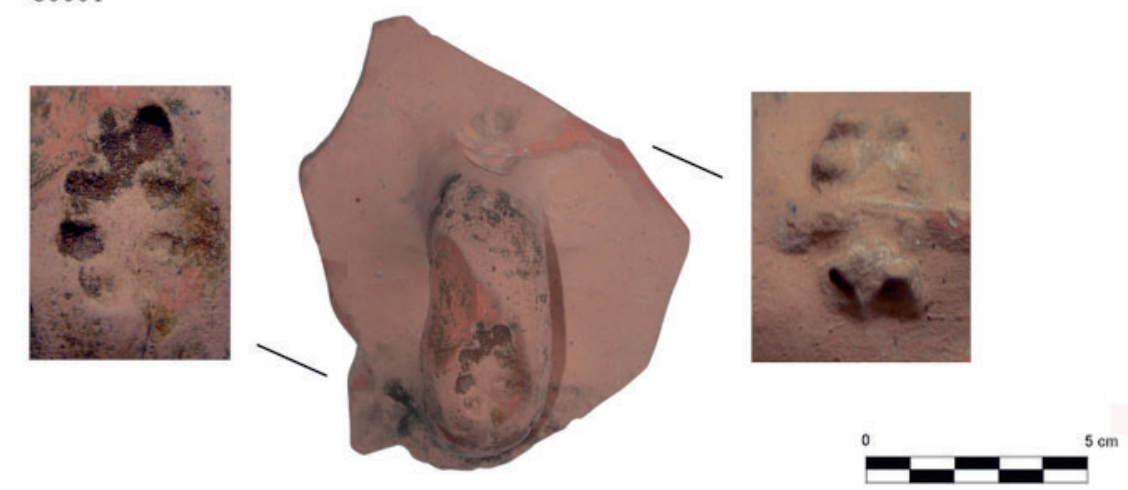

Figura 6: Impresiones con estampilla oval o circular (B), anepigráficas (* sin escala): Kelin, 16018; La Atalaya, 70001 (fotografía E. Collado); La Bastida de les Alcusses, 64001/2 (según J. Vives-Ferrándiz); Rambla de la Alcantarilla, 80001.

con una oreja y la boca abierta, la cresta descansando sobre el cuello y parte del lomo. Estilísticamente evoca modelos orientales y griegos similares a los representados en los objetos metálicos (Mata et alii, 2014, 137-141). La figura del grifo es la primera vez que se documenta como marca, por lo que suponemos que se pudo emplear como matriz un anillo-sello o una plaquita de bronce. Descontextualizado, se fecha a partir de la cronología general yacimiento entre los siglos IV-II a. C. Como ya se ha señalado se une a los otros dos ejemplares que utilizan un objeto personal para realizar la marca.

\subsubsection{Impresas Epigráficas}

La única marca recopilada dentro de este grupo presenta un enmarque rectangular de ángulos redondeados, incompleto, en cuyo interior se aprecian tres signos. Se encontró en Iesso ${ }^{19}$ y se lee como «s.u.be...»,

19. Los análisis efectuados en residuos encontrados en algunas de las ánforas ibéricas (más de 150 documentadas) indican un alto contenido en levaduras de cerveza (Pera, 2003). interpretado como un antropónimo por sus paralelos en otros soportes (Fig. 5, 101002) (Pera, 2003, 249 y 252 , figs. $4-30$ y 6-30).

\subsubsection{Marcas incisas}

A diferencia de lo que ocurría en el trabajo anterior, las marcas incisas catalogadas son más numerosas que las impresas (Fig. 2). Es una manifestación amplia y de diseños muy variados, documentándose desde el siglo VI a. C., en Alt de Benimaquia y el pecio de Cala Sant Vicenç, hasta los siglos II-I a. C. en Can Vilà, Sant Miquel y Olérdola, entre otros lugares.

\subsubsection{Incisas Anepigráficas}

Conocemos 37 nuevas ánforas en 22 yacimientos. Las incisiones se plasman de forma preferente sobre el hombro y el tercio superior, lo que las hace muy visibles y las pone en relación con su significado, destino o lote. En un cargamento de ánforas se podrían discriminar rápidamente unas de otras y de hecho son las que se han encontrado más alejadas de sus lugares de origen. 

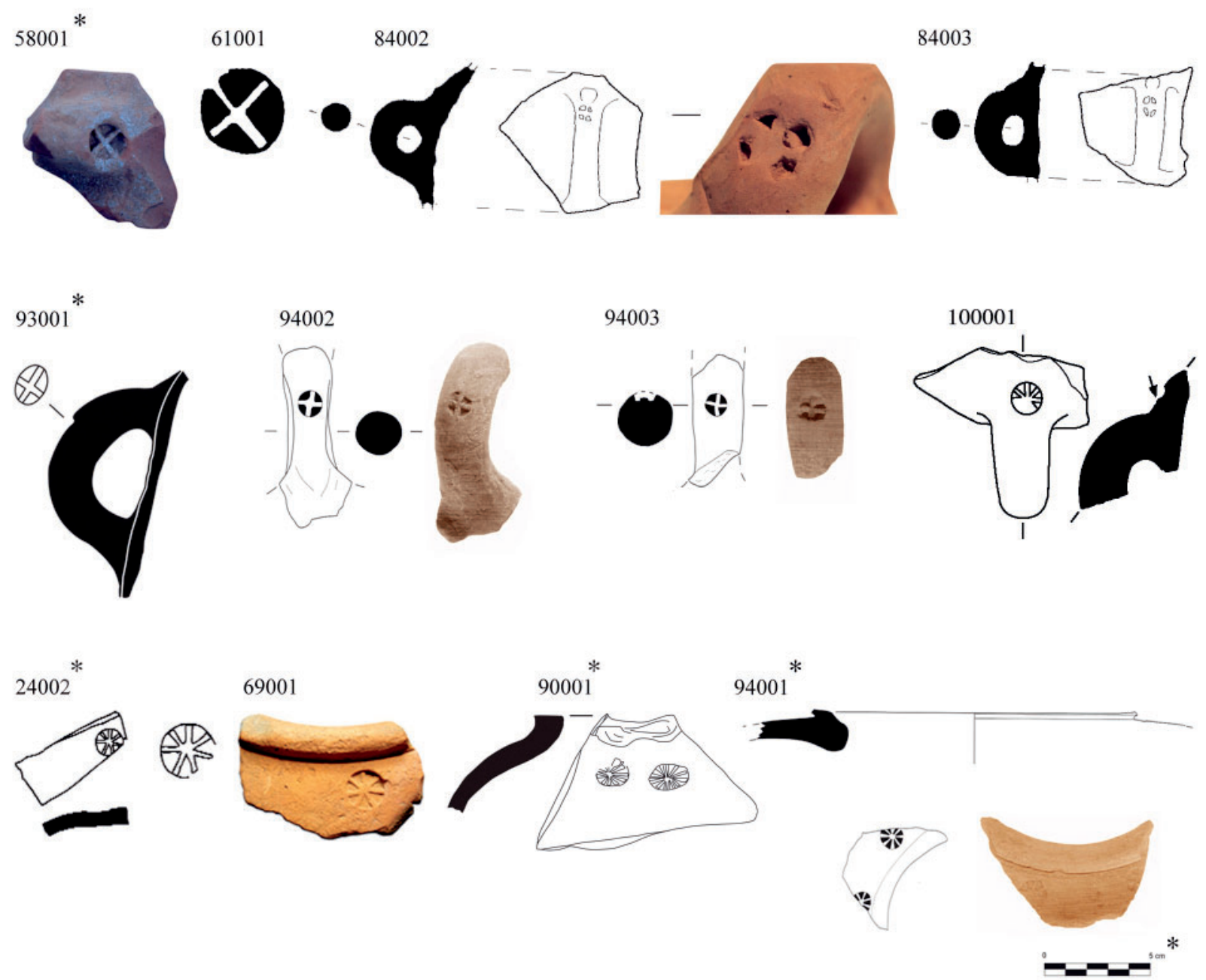

Figura 7: Impresiones con estampilla circular (B), anepigráficas (* con escala): Covarrobles, 58001 (fotografía F. Moya); Tossal del Moro de Pinyeres, 61001 (según Pérez Suñé y Revilla, 1999); El Vilar, 84002/3 (según Fabra y Vilalta, 2008); Rhode, 93001 (según Puig y Martín, 2006); Olèrdola, 94001/3 (según Molist, 2009); Alorda Park, 24002 (según Sanmartí et alii, 1998); Son Catlar, 69001 (fotografía J. de Nicolás); Saiti, 90001 (según J. Pérez Ballester).

Tienen una mayor diversidad de diseños, aunque en ocasiones exista cierta similitud entre ellos. Hay que tener en cuenta que estos signos se trazaban a mano alzada y con un instrumento de punta fina o roma, lo que lógicamente hace imposible que haya marcas exactamente iguales. En unos casos, consisten en dos o tres trazos simples que se entrecruzan; en otros, forman motivos algo más complejos; y, por último, existen unas marcas poco cuidadas, realizadas posiblemente a peine, sobre el hombro. Pasaremos a comentarlas por yacimientos, excepto estas últimas por tener un área de producción conocida.

De Binisafúller hay siete marcas, tres de ellas incompletas (Fig. 8, 23023/24 y 23029). Algunas se parecen a otras de este mismo pecio ya publicadas, lo que confiere cierta homogeneidad al conjunto (Fig. 8, 23026/7 y 23029; Fig. 9, 23025) (Mata y Soria, 1997, fig. 14, 23.019, 23.158, 23.159 y 23.163). Otras, tienen paralelos más o menos cercanos con ánforas de otros lugares y cronologías como Cerro Macareno de los siglos V al III a. C. (Fig. 9, 23025) (Mata y Soria, 1997, 306, fig. 6, 01.068) y Can Miralles/Can Modolell de los siglos III-II a. C. (Fig. 8, 23027) (Mata y Soria, 1997, 312-313, fig. 17, 32.166). Y las dos últimas, presentan marcas incisas sobre el hombro similares a las procedentes de los alfares de Illeta del Banyets y Tossal de les Basses (Fig. 10, 23032/33) (Guerrero y Quintana, 2000, fig. 7, 40 y 41).

El lote de ánforas con marcas, todas ellas incisas, recuperadas en este pecio son un buen ejemplo para confirmar el sentido comercial de las mismas, como puede ser el origen, la propiedad o el contenido. Descartamos el precio o la cantidad pues no se han identificado como numerales, ni éstas ni las epigráficas.

En cambio, en el pecio de Cala Sant Vicenç, mucho más antiguo (520-500 a. C.), sólo se encontró una marca sobre el galbo, consistente en dos líneas paralelas, onduladas (Fig. 9, 92001) (Nieto y Santos, 2008, fig. 153).

En Carmona se conoce una ánfora con marca incisa sobre el hombro compuesta por tres líneas que convergen en un punto, fechada en la segunda mitad del siglo V a. C. (Fig. 8, 56001) (Belén, 2006, fig. 12, 5). Es parecida a otras del Cerro Macareno y de Binisafúller 


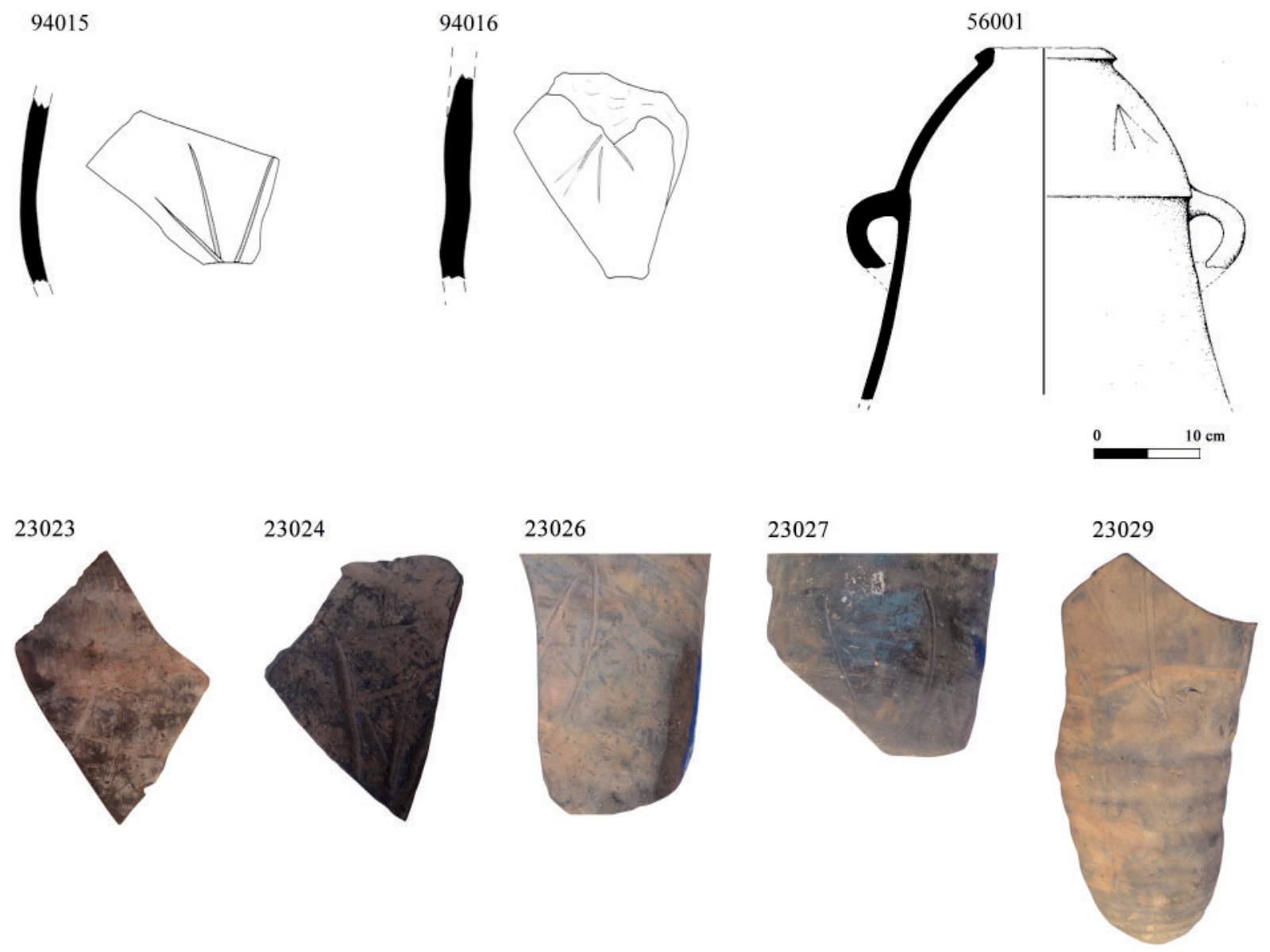

Figura 8: Incisiones anepigráficas (varias escalas): Olèrdola, 940015/6 (según Molist, 2009); Carmona, 56001 (según Belén et alii, 1997); Binisafúller, 23023/4, 23026/7 y 23029 (fotografías X. Aguelo).

(Mata y Soria, 1997, fig. 6, 01.073; fig. 14, 23.162). También podría interpretarse como epigráfica si se asocia al signo «to» dispuesto del revés.

En Alt de Benimaquia hay una marca sobre el hombro (Fig. 9, 71001) formada por tres líneas paralelas que llegan casi a la carena, fechada entre fines del siglo VII y el VI a. C. El diseño es similar a dos del pecio de Binisafúller aunque difieren en la disposición y la cronología (Fig. 9, 23025) (Mata y Soria, 1997, fig. 14, 23.019). También hay tres trazos incisos, en esta ocasión sobre borde, de El Pajarillo (Fig. $9,115001)$.

De Olèrdola proceden tres marcas fechadas en el segundo cuarto del siglo I a. C. Una, sobre asa, consiste en un trazo irregular de tendencia ovalada (Fig. 9, 94004), mientras que las otras dos, incompletas, se localizan en el galbo (Fig. 8, 94015/16) (Molist, 2009, fig. 11, 4 y 44). Si suponemos que los trazos se prolongan, tienen un gran parecido con dos marcas de Kelin (Mata y Soria, 1997, fig. 12, 16.181 y 16.182).

En otros yacimientos se han localizado asas en cuyos nervios se han trazado una o varias incisiones transversales (Fig. 9, 16019/20, 59001 y 74001), diseño muy simple pero que no parece fortuito y que también se había documentado con anterioridad (Mata y Soria, 1997, fig. 12, 16.183 y 16.184; fig. 16, 30.194).
Las cronologías de estos hallazgos oscilan entre los siglos IV y III a. C.

Finalmente, hay que destacar la homogeneidad de unas incisiones, poco cuidadas, realizadas posiblemente a peine sobre el hombro de las ánforas y que denominaremos contestanas para abreviar. Los primeros ejemplares fueron recogidos por Ribera (1982) pero sin considerarlos una producción homogénea. Más adelante los trabajos de Álvarez sirvieron para definir los atributos más destacables de este tipo de ánforas, incluyendo entre los mismos «la decoración peinada», y considerarlas fabricadas en el alfar de Illeta dels Banyets (Álvarez, 1997, 152; Álvarez, 1998). Excavaciones posteriores en los testares de dicho alfar y en el área artesanal del Tossal de les Basses han servido para confirmar que esta marca es una peculiaridad de ambos lugares (Fig. 10, 97002; Fig. 11, 111001/3) (López Seguí, 1997, 241, fig. 8,2; 2000, 247; Rosser et alii, 2003, 81 y 142, fig. 68, 2; Rosser y Fuentes, 2007, 53, 108 y 109). Desafortunadamente todavía no se ha publicado un NMI procedente de los hornos y los pocos ejemplares completos que se conocen muestran una gran variedad de perfiles y tamaños (Figs. 10 y 11). Variedad que puede deberse a alfares, contenidos y/o cronología diferentes. A pesar de todas estas dificultades, lo cierto es que todas 


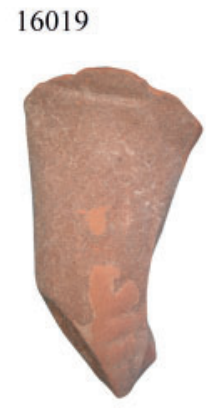

16020
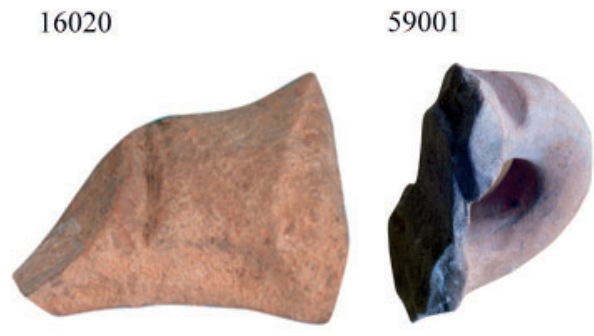

74001
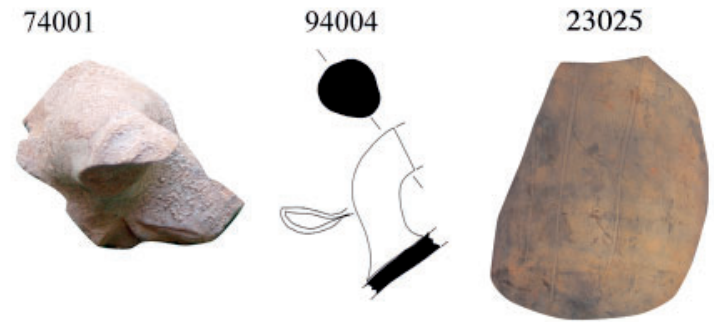

71001

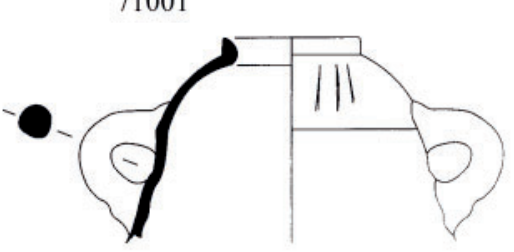

92001

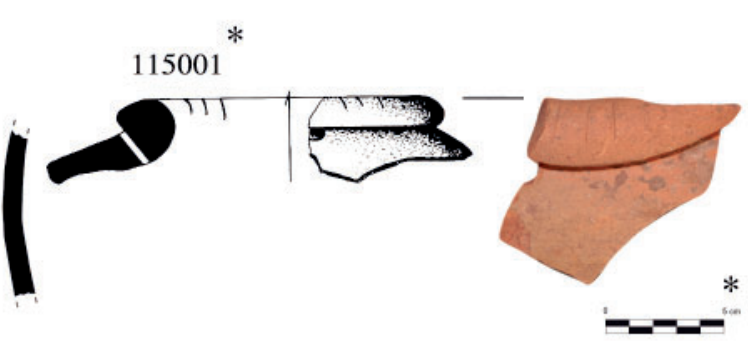

Figura 9: Incisiones anepigráficas (varias escalas): Kelin, 16019/20; P.U.R.-2, 59001; Tos Pelat, 74001 (fotografía J. Burriel); Olèrdola, 94004 (según Molist, 2009); Binisafúller, 23025 (fotografía X. Aguelo); L’Alt de Benimaquia, 71001 (según Álvarez et alii, 2000); Cala Sant Vicenç, 92001 (según Nieto y Santos, 2008); El Pajarillo, 115001 (Dibujo y Fotografía Instituto de Investigación en Arqueología Ibérica, Universidad de Jaén).

estas ánforas se han encontrado en ambos alfares y sus testares en una cantidad indeterminada, en los asentamientos próximos a ellos (Fig. 10, 62001/2 y 109001; Fig. 11, 109002) y en otros de la provincia de Alicante (Fig. 10, 52002, 55005, 108001/2 y 112001; Fig. 11, $12005 / 6$ y $55003 / 4)$.

Fuera del ámbito contestano se han publicado un ejemplar del alfar de Camí de Vista Alegre del siglo III a. C. (Fig. 11, 30006); otros cuatro en Puig de Sant Andreu del siglo IV a. C. como las contestanas (Fig. 11, 45006/9); además de varias piezas en Menorca y Mallorca también con fechas similares a las de Illeta dels Banyets y Tossal de les Basses (Fig. 10, 23032/33, 113001 y 114001). Es necesario recalcar que la cantidad de ánforas con estas características es muy superior a la publicada pues las localizadas en los alfares no se han cuantificado y lo mismo puede suceder con su presencia en otros asentamientos donde no se han considerado como marcas.

\subsubsection{Incisas Epigráficas}

Son menos numerosas que las anepigráficas (Figs. 2 y 12). Se han localizado en ocho yacimientos, seis de los cuáles están en Catalunya. Los epígrafes pueden ser tanto signos aislados como letreros más largos, dispuestos preferentemente en el galbo; como los anteriores, en zonas fácilmente visibles. En términos generales se advierte que la costumbre de plasmar incisiones epigráficas se inicia en el siglo IV a. C., como se evidencia en Binisafúller, y continúa hasta los siglos II y I a. C. (Tossal de les Tenalles, Sant Miquel y La Fuencubierta). Como sucedía con los epígrafes impresos, los letreros más largos tienen la cronología más reciente (Mata y Soria, 1997, 330).
Signos aislados: Generalmente se emplea un solo signo, aunque hay dos casos con dos (Fig. 12). El más repetido es el aspa que interpretamos como da $/ \mathrm{ta}^{20}$, en dos ánforas de Olérdola (94012 y 94014) y en otras dos de La Fogonussa (Fig. 96004 y 96005) ${ }^{21}$.

De Binisafúller proceden tres signos aislados:

- El signo «te», es decir, una circunferencia con un aspa inscrita (23028) que se encuentra también en un asa de Illa d'en Reixac (46002).

- Una circunferencia con el diámetro indicado podría leerse como el signo «de» (Ferrer, 2010, fig. 1) (23030), con paralelo en Cerro Macareno (Mata y Soria, 1997, fig. 6, 01.060).

- Y el tercero (23031), en forma de «V», podría interpretarse como el signo «m».

Una marca epigráfica doble, aunque incompleta, podría ser la 23029 (Fig. 8), en cuyo caso debería leerse como «ba.m.». Otro epígrafe con dos signos es el de Can Vilà (Fig. 12, 75001), leído como «ba.ka.», fechado en siglos II-I a. C. Los autores señalan que hay otros similares en diferentes soportes (Coll et alii, 2002, fig. 6, 23).

Letreros: Este grupo está constituido por tan sólo tres piezas (Fig. 12). En La Fuencubierta (63001) se encontró un letrero incompleto del que se conservan cuatro signos, leidos como «i./a.ta.u...» en el

20. Ya señalábamos en el anterior trabajo los motivos por los que interpretamos el aspa como la letra ibérica da/ta (Mata y Soria, 1997, 346)

21. Los autores no las consideran epigráficas (Garcés y Torres, 2011, 49-50). 

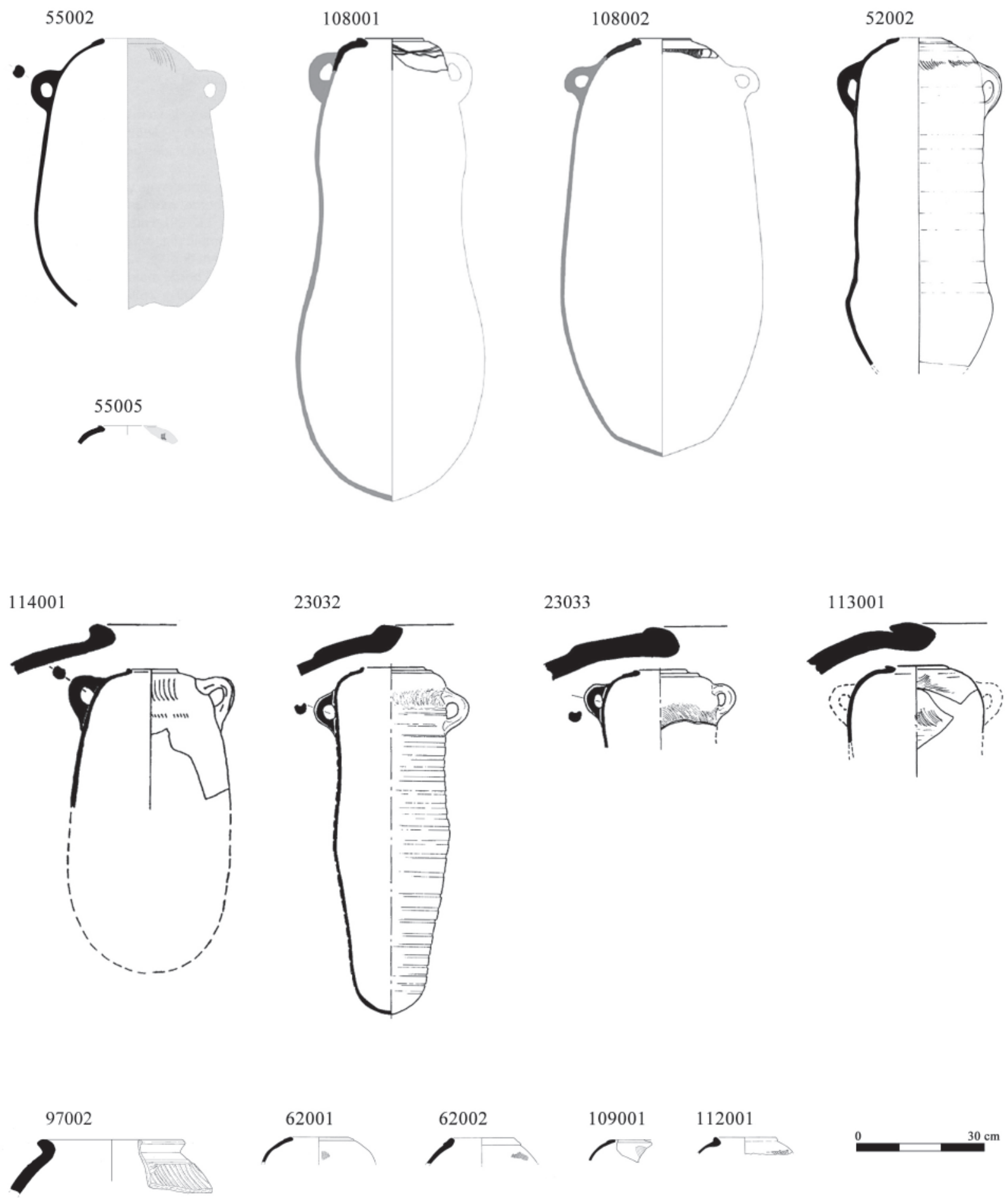

Figura 10: Incisiones anepigráficas: El Puig, 55002 y 55005 (según Grau y Segura, 2013); Colmenares, 108001/2 (según Moratalla y Segura, 2013); El Puntal, 52002 (según Hernández Alcaraz y Sala, 1996); Puig de sa Morisca, 114001 según Guerrero y Quintana, 2000); Binisafúller, 230032/3 (según Guerrero y Quintana, 2000);); Cales Coves, 113001 (según Guerrero y Quintana, 2000); Illeta dels Banyets, 97001 (según López Seguí, 1997) y 62001/2 (según Álvarez, 1998); Lucentum/Tossal de Manises, 109001 (según Ribera, 1982); Benimassot, 112001 (según Grau, 2002).

signario ibérico meridional. El del Tossal de les Tenalles también tiene tres signos conservados (86001), leidos como «ta.r.ti...» (Garcés y Pérez Conill, 2006). Y, el tercero, de Sant Miquel (83001), sobre el borde de un ánfora, consta de siete signos leídos como «i.s.ke.l.a.ke.r.», interpretado como un antropónimo (Genera, 2005, 1001). Ninguno de ellos tiene un contexto preciso aunque pueden datarse, por los materiales asociados, entre finales del siglo III y los siglos II-I a. C. 


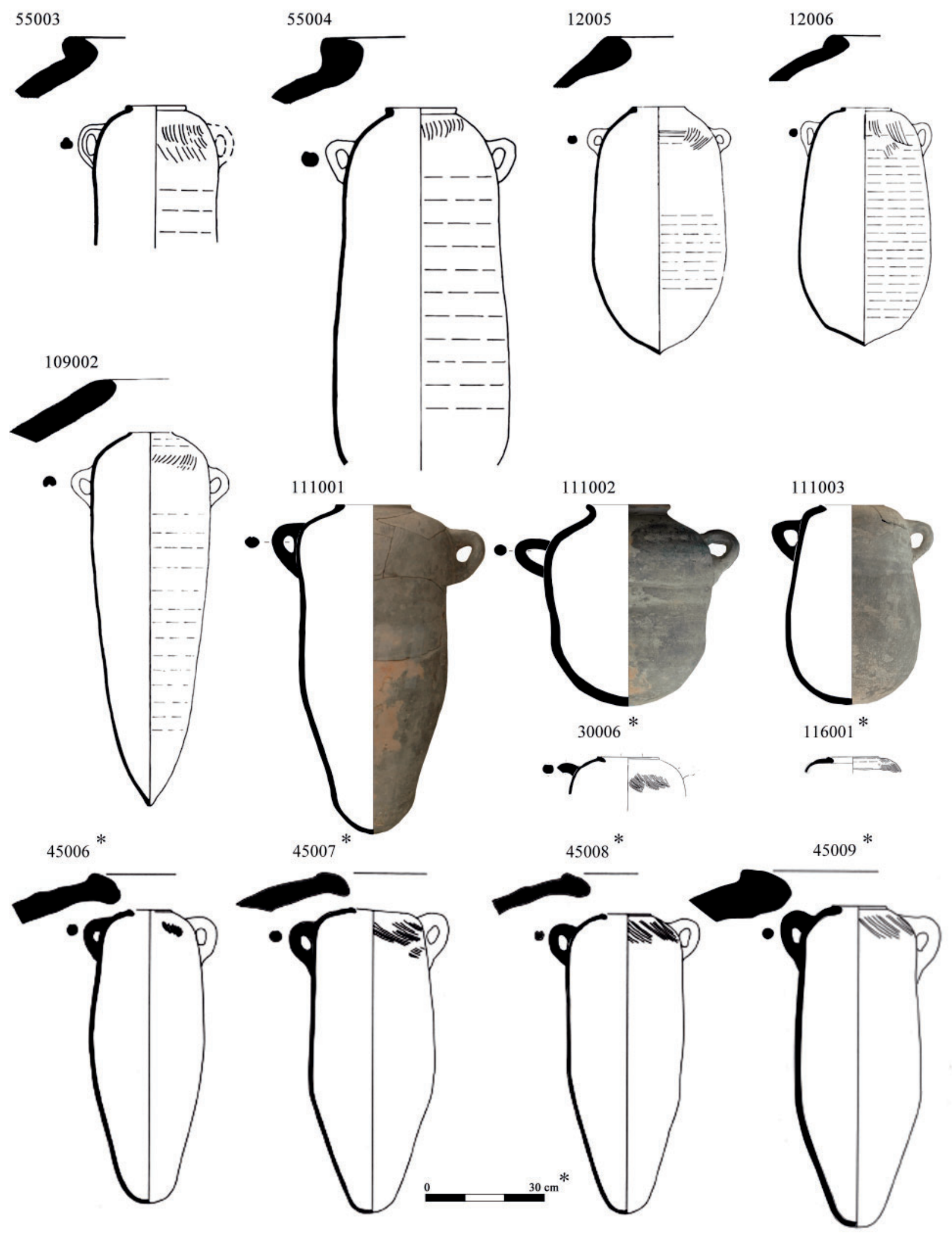

Figura 11: Incisiones anepigráficas (* con escala): El Puig, 55003/4 (según Ribera, 1982); La Serreta, 12005/6 (según Ribera, 1982); Lucentum/Tossal de Manises, 109002 (según Ribera, 1982); Tossal de les Basses, 111001/3 (según Rosser y Fuentes, 2007); Camí de Vista Alegre, 30006 (según AA.VV., 1995); Tossal de les Basses, 116001 (según Rosser et alii, 2003); Puig de Sant Andreu, 45006/9 (según Sanmartí y Bruguera, 1998). 

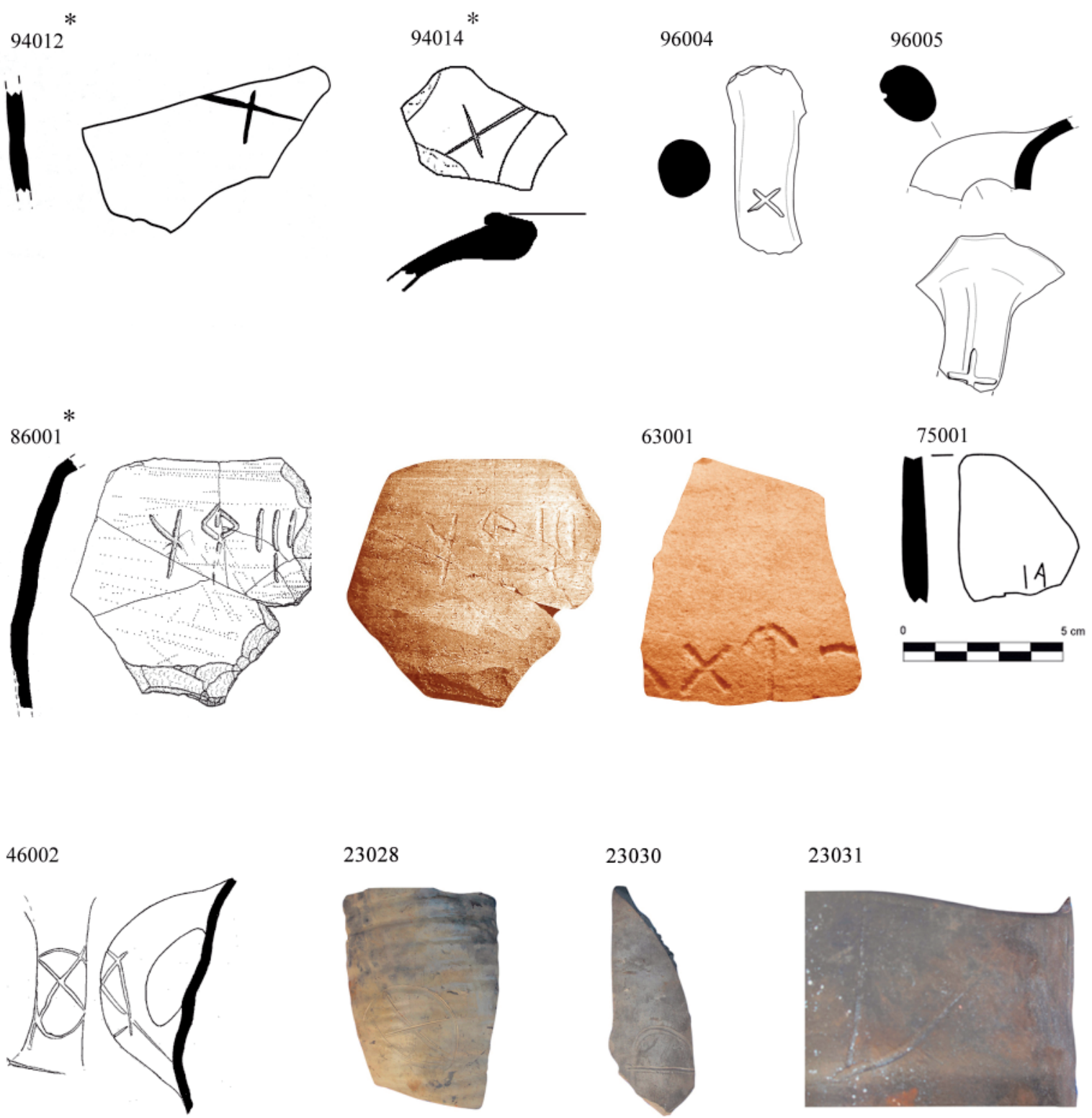

23028

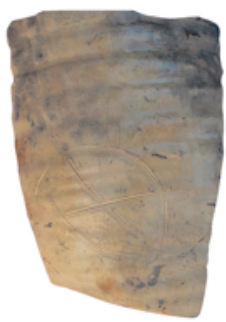

23030

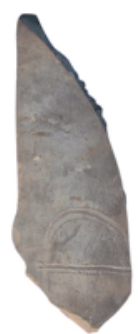

23031

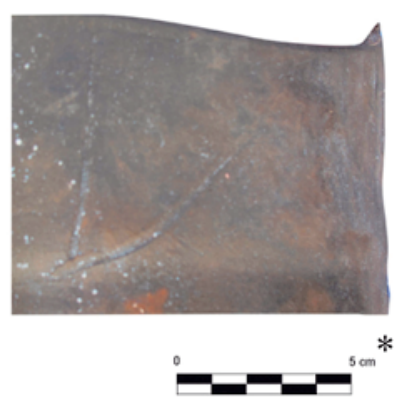

Figura 12: Incisiones epigráficas (* con escala): Olèrdola, 94012 y 94014 (según Molist, 2009); La Fogonussa, $96004 / 5$ (según Garcés y Torres, 2011); Tossal de les Tenalles, 86001 (según Garcés y Pérez Conill, 2006); La Fuencubierta, 63001 (según Martínez Castro y Tristell, 1999); Can Vilà, 75001 (según Coll et alii, 2002); Illa d’en Reixac, 46002 (según Martín et alii, 1999); Binisafúller, 23028 y 23030/1 (fotografías X. Aguelo).

\subsection{MARCAS POSTCOCCIÓN}

Las marcas postcocción son menos numerosas que las anteriores y pueden ser esgrafiadas, pintadas o a carbón, siendo estas dos últimas técnicas las de identificación más reciente y con menos posibilidades de haber sobrevivido a los avatares postdeposicionales (Figs. 2 y 13). Su interpretación es más compleja pues se pueden haber realizado en cualquier momento, aunque en otro tipo de soportes (cerámicas griegas, campanienses, pondera o fusayolas, entre otros), suelen considerarse como marcas de propiedad o de carácter comercial.

\subsubsection{Esgrafiadas epigráficas}

Los epígrafes esgrafiados son escasos y casi todos ellos se componen de un solo signo. Tienen una amplia dispersión geográfica y se fechan desde finales del siglo VI a. C., como el esgrafiado de Pech Maho (510450 a. C.), hasta en el siglo I a. C. (Fig. 13).

$\mathrm{Al}$ igual que en las incisiones, el signo más repetido es «da/ta» que se encuentra en cuatro ánforas (60001; Fig. 14, 57001, 99001 y 107001). Un signo leído como «S» se localiza en un asa de Los Terreros (Fig. 14, 78001). Y en el hombro de un ánfora ibérica de Pech Maho (Fig. 14, 95011) aparece lo que interpretamos 


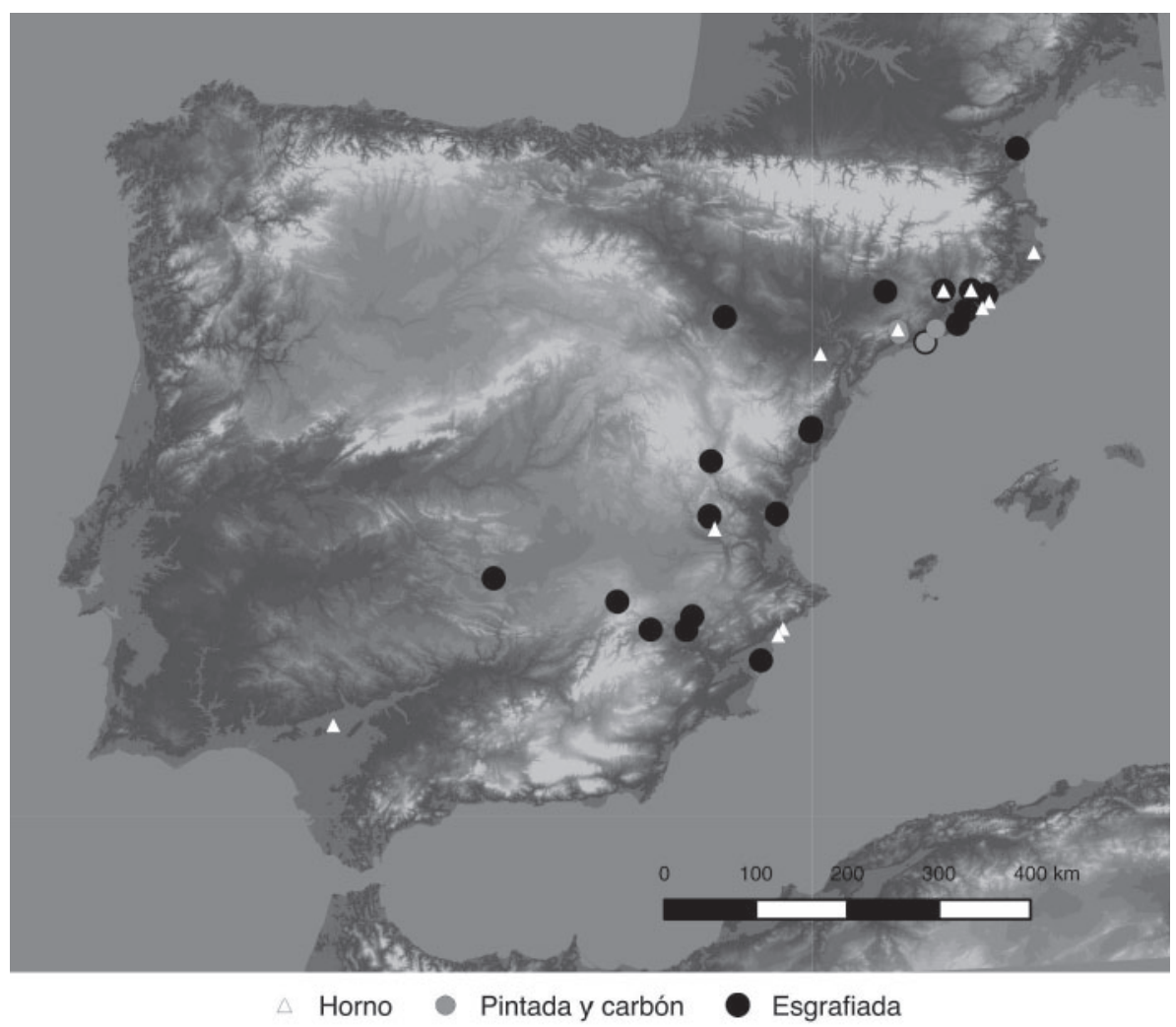

Figura 13: Distribución de las marcas postcocción.
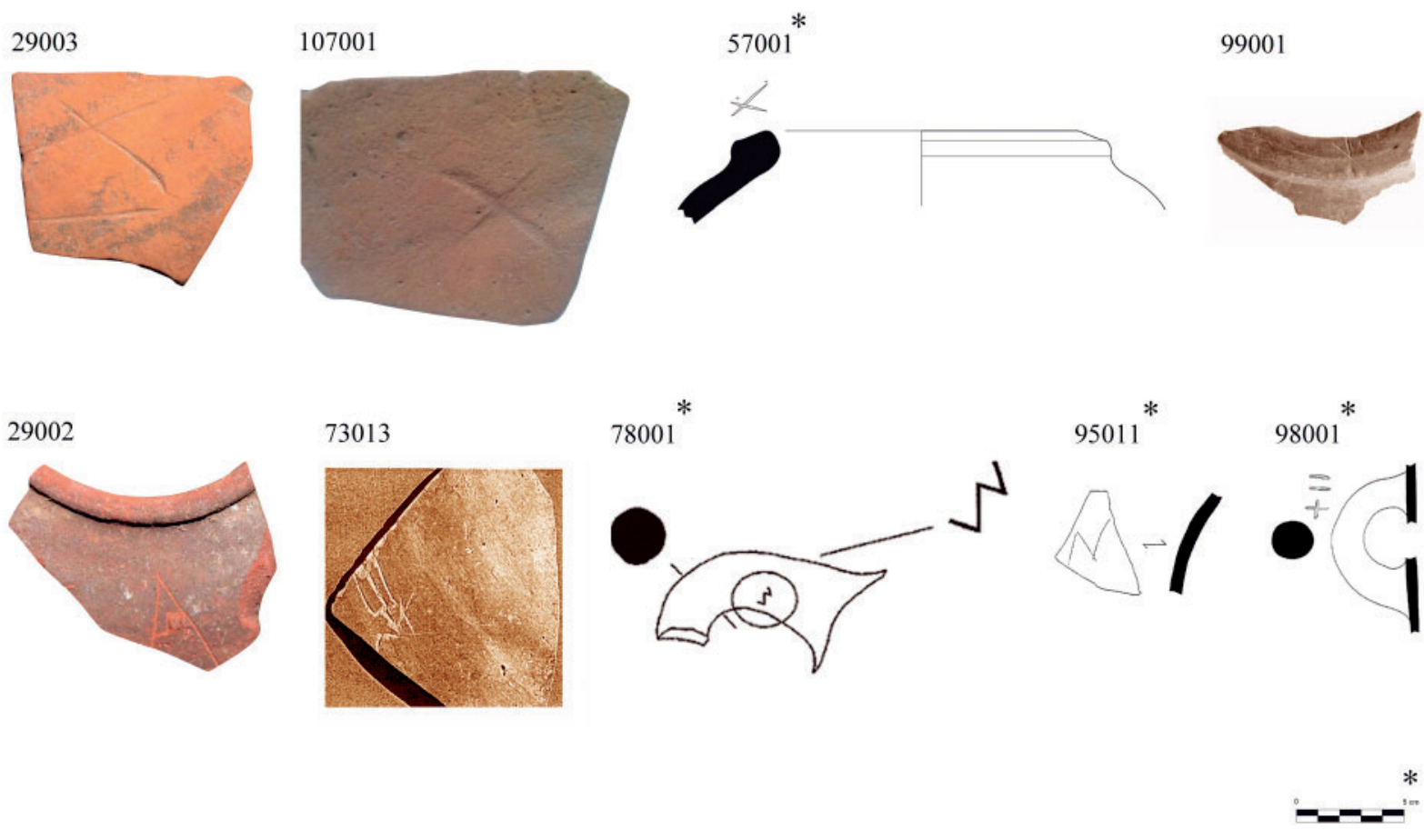

Figura 14: Esgrafiados epigráficos (* con escala): Turó de Ca n’Olivé, 29002/3 (según Francés et alii, 2008); El Tobar, 107001; La Piedra de Peñarrubia, 57001; Alarcos, 99001 (Carrasco y Velaza, 2011); Contrebia Belaisca, 73013 (según Díaz y Jordán, 2001); Pech Maho, 95011 (según Gailledrat y Solier, 2004); Molí d’Espígol, 98001 (según Cura, 2006). 

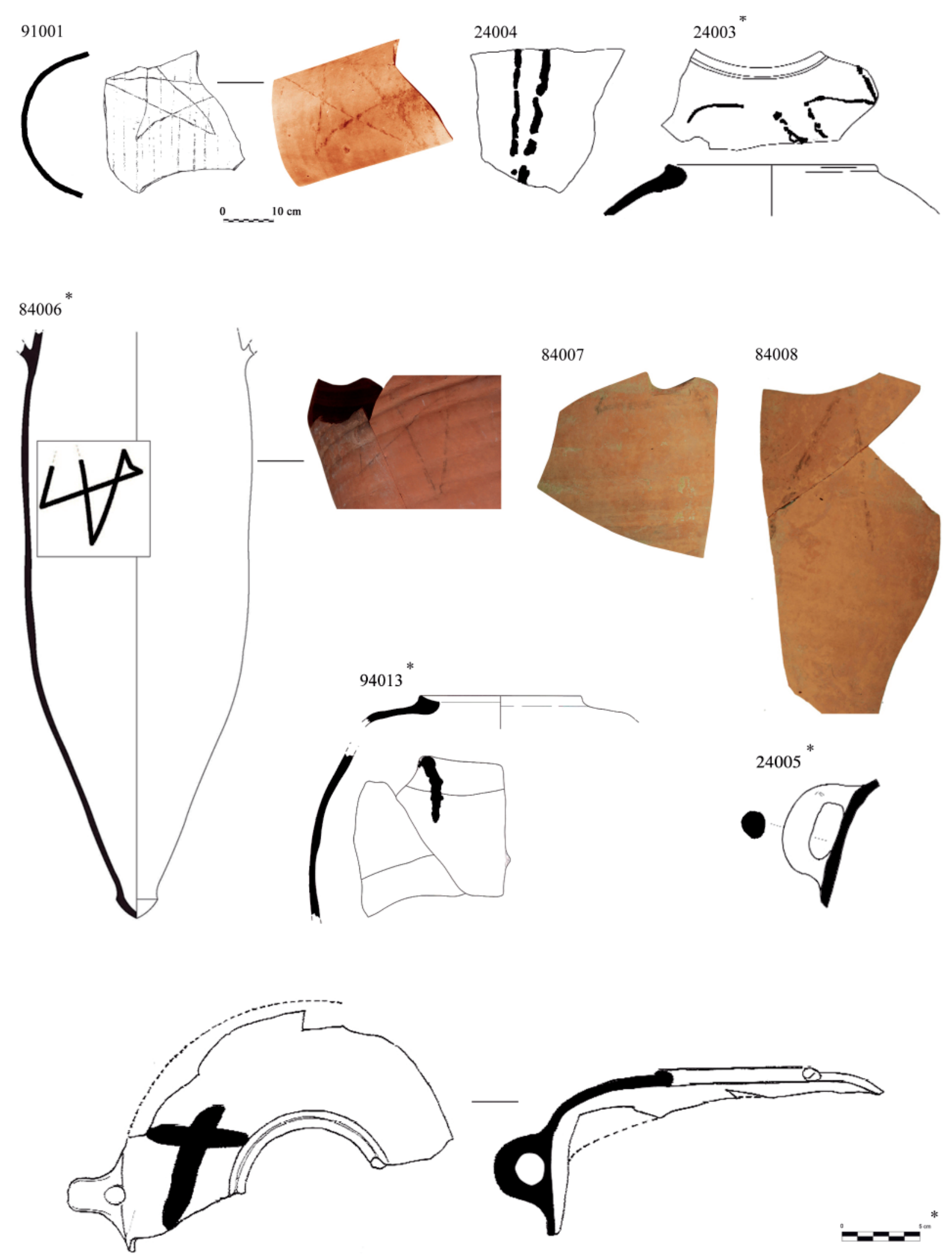

Figura 15: Marcas a carbón (* con escala): Fontscaldes, 91001 (según Solé, 2008 y Fabra et alii, 2013); Alorda Park, $24003 / 4$ (según Sanmartí et alii, 1998); El Vilar, 84006/8 (según Fabra et alii, 2013). Marcas con pintura roja: Olèrdola, 94013 (según Molist, 2009); Fontscaldes, 91002 (según Solé, 2008); Alorda Park, 24005 (según Sanmartí et alii, 1998). 


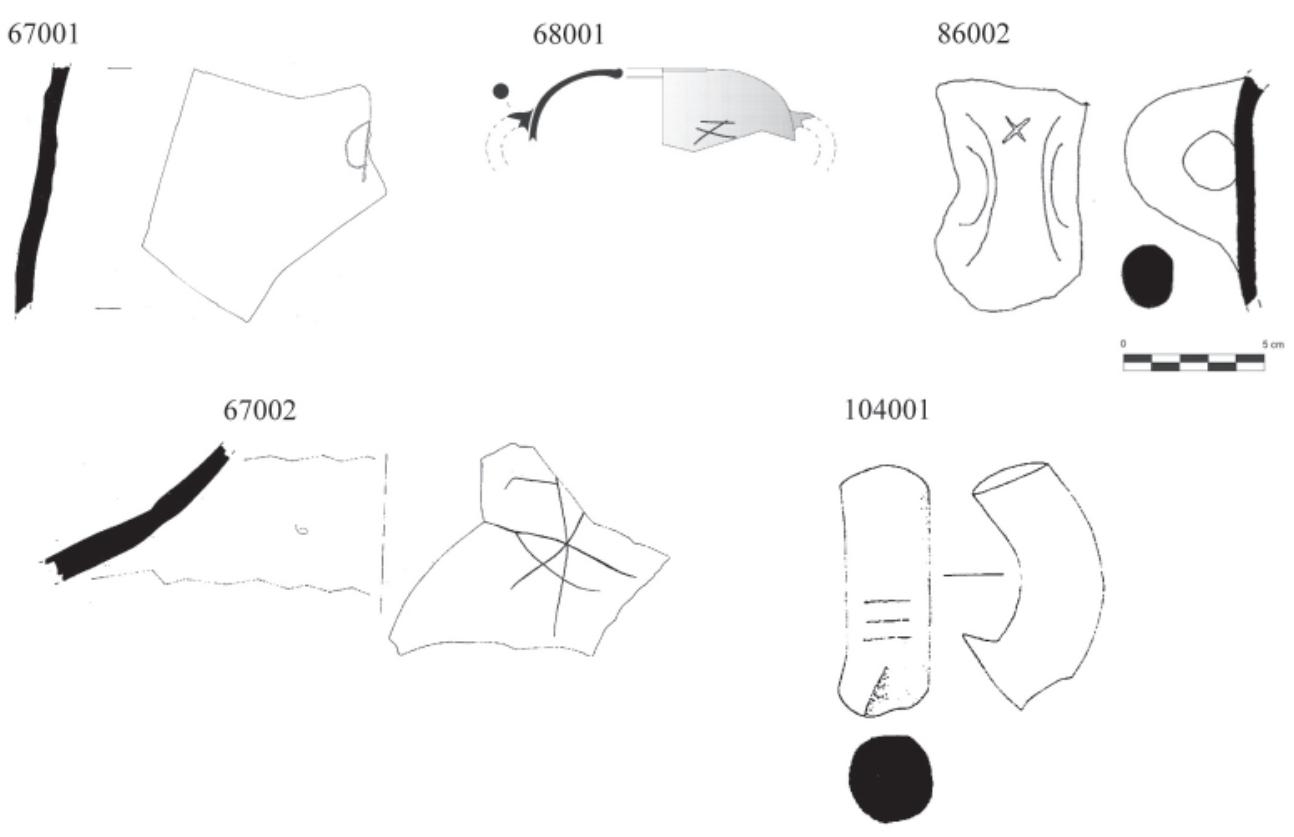

Figura 16: Marcas incisas o esgrafiadas (varias escalas). Epigráficas: La Picola, 67001 (según Badie et alii, 2000); Lattara, 68001 (según Py et alii, 2001); Tossal de les Tenalles, 86002 (según Garcés y Pérez Conill, 2006). Anepigráficas: La Picola, 67002 (según Badie et alii, 2000); Montbarbat, 104001 (según Pujol, 1989).

como una «n» en alfabeto grecoibérico, aunque también puede tratarse de una letra griega (Gailledrat y Solier, 2004, 348-349, fig. 279-4).

En el Turó de Ca n'Olivé hay dos marcas de uno y dos signos, si bien ambas pueden estar incompletas (Fig. 14). La primera parece una «A» griega, datada en la primera mitad del siglo III a. C. (29002); y la segunda, de los siglos II-I a. C., se puede leer «ta.ba.»o «ba. ta.» (29003) y podría tratarse de un numeral (Francés et alii, 2008, 225, fig. 17).

Algo más largos son otros dos epígrafes. Sobre un galbo de ánfora de Contrebia Belaisca (Fig. 14, 73013) tres signos entrelazados ofrecen diversas lecturas: «ke. ten.», «ke.ton.» o «ke.tin.» (Díaz y Jordán, 2001, 312313, fig. 20). Y, en segundo lugar, en un asa de Molí d'Espígol se han grabado tres signos interpretados como un numeral (Fig. 14, 98001) (Cura, 2006, 139, lám. 28.5).

\subsubsection{Pintadas y a carbón}

Estas marcas, realizadas con pintura o carbón después de la cocción, se han reconocido recientemente y son poco numerosas (Fig. 2). Hoy por hoy tenemos seis trazadas a carbón y tres pintadas (Fig. 15). Resulta interesante destacar varios aspectos: casi todas ellas son anepigráficas excepto dos; se concentran en un área relativamente cercana de Cataluña (El Vilar, Fonstcaldes, Olèrdola y Alorda Park) (84006, 91001/2, 94013, 24003/5); dos de ellas proceden de un testar de Fontscaldes (91001 y 91002); en general se disponen sobre el hombro o el tercio superior; y las más antiguas, del siglo IV a. C., son las de Alorda Park, mientras que el resto se data entre finales del siglo III y principios del I a. C.

De Alorda Park se han publicado dos marcas a carbón sobre el galbo y el hombro (24003 y 24004) y una tercera que es una pequeña mancha roja sobre asa que no parece fortuita (24005). Una de las marcas de Fontscaldes, realizada a carbón en el galbo, es una estrella de cinco puntas (Solé, 2008, 309, fig. 190, 3; Fabra et alii, 2013, fig. 1) (91001); y la segunda, es el signo «da/ta» pintado sobre hombro (91002). Del asentamiento próximo de El Vilar se han publicado tres marcas a carbón incompletas, una de ellas un posible «ko.» (84006/8) (Fabra et alii, 2013, 284, fig. 2). $\mathrm{Y}$, de Olèrdola, un hombro de un ánfora con un trazo pintado en rojo (94013).

\subsection{MARCAS INDETERMINADAS}

Recogemos en este apartado un pequeño conjunto de marcas de las que no se indica, en las publicaciones, si se trata de incisiones o esgrafiados (Figs. 2 y 16).

Dos de ellas son anepigráficas y proceden de $\mathrm{La}$ Picola y Montbarbat (Fig. 16). La primera consiste en una serie de líneas entrecruzadas y se ubica en el tercio superior del recipiente (Badie et alii, 2000, fig. 72, 2). Por la complejidad de su diseño podría ser incisa (67002). Descontextualizada, se fecha como el yacimiento, entre los siglos V-IV a. C. La segunda es un asa con tres trazos cortos transversales (104001) y tiene similitudes con otra del Camí de Vista Alegre clasificada como incisa (Mata y Soria, 1997, fig. 16, 30.194). 
Las epigráficas son cuatro, casi todas ellas de un solo signo (Fig. 16). El signo «da/ta» se encuentra sobre un asa del Tossal de les Tenalles (86002) (Pérez Conill, sin año, 101, lám. 7, 4) ${ }^{22}$. En un fragmento de La Picola (67001) hay un signo que se puede leer como «r» (Badie et alii, 2000, fig. 72, 1). En Lattara hay un posible numeral (68001) que recuerda al esgrafiado de Molí d'Espígol (Fig. 14, 98001) y a uno inciso de Binisafúller (Mata y Soria, 1997, fig. 14, 23.070). Y, por último, de Sant Miquel (83002) se cita un signo sobre galbo, del que no se acompaña ilustración (Genera, 2005, 1002).

\section{CONCLUSIONES}

Con la publicación de este nuevo repertorio se conocen ya 270 marcas sobre ánfora dispersas por toda la geografía ibérica y de variada cronología ${ }^{23}$. Se trata de una cantidad bastante significativa que no debería quedarse al margen de los estudios sobre ánforas ibéricas por la información que pueden aportar sobre los lugares de producción y la distribución de productos (Ribera y Tsantini, 2008).

La tendencia observada en 1997 en los distintos conjuntos se mantiene, lo que permite entrever la existencia de ciertas pautas:

- Las marcas impresas anepigráficas constituyen el segundo grupo más numeroso y se aplican, sobre todo, en las asas, mientras que las epigráficas son anecdóticas.

- Las incisas anepigráficas, por el contrario, se sitúan preferentemente en el galbo o en el hombro. Su carácter comercial es el más evidente pues también se han encontrado fuera del ámbito cultural ibérico.

- Entre las marcas postcocción, las epigráficas son mayoritarias y se plasman indistintamente en cualquier parte del recipiente. Entre ellas, las realizadas con pintura roja y con carbón suponen una novedad con respecto al trabajo anterior y sólo se han identificado en un área restringida de Cataluña.

- En cualquiera de las técnicas consideradas, los epígrafes son un conjunto escaso y de cronología tardía cuando tienen más de dos signos (siglos II-I a. C.). Los más antiguos, de los siglos V-IV a. C., presentan tan sólo uno o dos signos (Fig. 12, 23028, 23030/1; Fig. 16, 67001) (Mata y Soria, 1997, figs. 7, 5.039 y 6.020; 10, 12.014; láms. I-1, VII-1).

22. El autor indica que se trata de «un aspa impressa» pero por paralelos con otras marcas debe ser incisa o esgrafiada.

23. Su número es actualmente más elevado pues desde el envío de este trabajo para su revisión y publicación definitiva se han encontrado y publicado nuevas piezas. Estas novedades se recogerán en un nuevo catálogo.
Las marcas se encuentran en un número escaso en los yacimientos más antiguos (siglos VI-V a. C.) y va aumentando su presencia en las centurias posteriores, sobre todo, en los lugares de mayor tamaño, en algunos costeros y en el pecio de Binisafúller (Fig. 1). Se trata, por tanto, de un fenómeno de imitación de las prácticas procedentes del comercio fenicio y púnico, como se puede ver a través de su presencia en las primeras producciones anfóricas peninsulares de Iliberri (Granada) y Cerro de la Mora (Moraleda de Zafayona) (Roca et alii, 1988, 42, figs. 25, d y e; 29, n; Pachón y Carrasco, 2009, 373, fig. 11). La pieza más interesante es la del Cerro de la Mora pues tiene una marca bajo un asa muy parecida a otra encontrada en Canto Tortoso (Gorafe), aunque con una fecha más reciente (González Román et alii, 1995, 164, fig. 8, 11).

El significado de las marcas sobre ánfora sigue siendo objeto de debate al que se ha sumado la reciente propuesta de Fumadó (2014) al analizar la impresión figurada de El Macalón. Según este autor, el sellado de ánforas está encaminado a controlar las fases de producción, transporte, contenido o consumo por parte de algunos individuos o familias.

Lo cierto es que, según la técnica de realización y su posición, pudieron tener significados distintos. Entre las precocción, la facilidad con que se puede hacer una incisión en comparación con una impresión que necesita de la fabricación de una matriz que pudo utilizarse en repetidas ocasiones puede avalar también ciertas diferencias. Por ejemplo, las únicas marcas que, con una excepción por ahora, se encuentran fuera de la geografía ibérica son las incisas. Su hallazgo en los pecios de Cala Sant Vicenç, Cales Coves y Binisafúller sugiere que tuvieron un sentido más comercial y su cartografiado puede servir para detectar el origen de los productos comercializados (Soria y Mata e. p.).

Entre los ejemplos actualmente conocidos se detectan repeticiones que permiten vincularlas a determinados alfares y/o territorios. Los casos más emblemáticos son una impresión de forma ovalada que se encuentra en Kelin, en tres asentamientos de su territorio y en uno más alejado -La Bastida de les Alcusses(Fig. 6) (Mata y Soria, 1997, fig. 11, 16.003, 16.006 y 16.091; fig. 13, 18.011); y las impresiones circulares con cruz o aspa inscrita y la variante con motivo radial de siete u ocho brazos concentradas sobre todo en Cataluña, con las excepciones de Macalón (Mata y Soria, 1997, fig. 8, 07.030), Covarrobles, Saiti y Son Catlar (Fig. 7). Entre las incisas, el ejemplo más recurrente es el procedente de los alfares de Illeta dels Banyets y Tossal de les Basses (Figs. 10 y 11). A falta de un estudio exhaustivo de ambos lugares se puede decir que están identificando bien a los alfares bien al área de procedencia, es decir, la Contestania. Todas estas recurrencias ilustran la existencia de circuitos comerciales de diverso alcance, desde el local hasta la larga distancia (Soria y Mata, e. p.).

Excepcionales son dos marcas que pudieron estamparse con el chatón de un anillo. En una ellas se 
aprecia la figura de un grifo (Fig. 5, 96001) y en la otra un motivo que no se ha podido identificar (Fig. 5, 84001). Ambas se suman a las ya conocidas de El Macalón y La Serreta (Mata y Soria, 1997, fig. 8, 07.0021 y fig. 10,12.110). Al haberse realizado con sellos personales, habría que considerarlas marcas de propiedad del producto de manera que el receptor del contenido pudiera identificarlo fácilmente (Fumadó 2014).

Las marcas postcocción, como ya hemos señalado, pueden tener un abanico más amplio de posibilidades puesto que se han podido realizar en cualquier momento de la vida del contenedor, desde su origen hasta su destino final. Pero entre ellas abundan las epigráficas (Fig. 2), lo que puede estar apuntando hacia la propiedad de cualquiera de los agentes implicados -desde el productor hasta el consumidor- $y$, en el caso de los numerales, al precio o a la cantidad (Fig. 14, 29003 y 98001).

Los 11 hornos donde se documentan ánforas con marca no concentran un número importante con la única excepción de Cerro Macareno (Mata y Soria, 1997, 305-306, fig. 6), pero sí que tienen casi todos ellos marcas precocción de ambas técnicas o de una de las dos. A pesar de ello, las repeticiones y la concentración geográfica de esta práctica permitirán realizar aproximaciones al origen de estos productos y a sus circuitos de distribución. Trabajo que no puede abordarse aquí porque el objetivo de este artículo es ir completando el repertorio de marcas sobre ánforas ibéricas.

\section{INVENTARIO}

\begin{tabular}{|c|c|c|c|c|c|c|c|c|c|}
\hline Num & Yacimiento & Municipio & Forma & Clase & Técnica & Tipo & Cantidad & Ubicación & Cronología \\
\hline 56001 & Carmona & Sevilla & I.1.1. & Anep & Incisa & & 1 & Hombro & 2/2 s. V a.C. \\
\hline 63001 & La Fuencubierta & La Carlota & I.1. & Epi & Incisa & & 1 & Hombro & Ss. II-I a. C. \\
\hline 115001 & El Pajarillo & Huelma & I.1. & Anep & Incisa & & 1 & Borde & S. IV a.C. \\
\hline 99001 & Alarcos & Ciudad Real & I.1. & Epi & Esgrafiada & & 1 & Borde & Ss. V-I a.C. \\
\hline 57001 & Piedra de la Peñarrubia & Elche de la Sierra & I.1.2. & Epi & Esgrafiada & & 1 & Borde & Ss. V-I a.C. \\
\hline 107001 & El Tobar & Alcaraz & I.1. & Epi & Esgrafiada & & 1 & Galbo & Ss. III-II a.C. \\
\hline 12005 & La Serreta & $\begin{array}{l}\text { Alcoi-Cocentaina- } \\
\text { Penàguila } \\
\end{array}$ & I.1.2.4. & Anep & Incisa & & 1 & Hombro & $\begin{array}{c}2 / 2 \text { s. III- } 1 / 4 \text { s. } \\
\text { II a.C. }\end{array}$ \\
\hline 12006 & La Serreta & $\begin{array}{l}\text { Alcoi-Cocentaina- } \\
\text { Penàguila } \\
\end{array}$ & I.1.2.4. & Anep & Incisa & & 1 & Hombro & $\begin{array}{c}2 / 2 \text { s. III- } 1 / 4 \mathrm{~s} . \\
\text { II a.C. }\end{array}$ \\
\hline 52002 & El Puntal & Salinas & I.1.2. & Anep & Incisa & & 1 & Hombro & 1/2 s. IV a. C. \\
\hline 55001 & El Puig & Alcoi & I.1. & Anep & Impresa & B & 1 & Asa & $\begin{array}{c}2 / 2 \text { s. V-inicios } \\
\text { s. IV a.C. }\end{array}$ \\
\hline 55002 & El Puig & Alcoi & I.1.2.4. & Anep & Incisa & & 1 & Hombro & $\begin{array}{c}2 / 2 \text { s. V-inicios } \\
\text { s. IV a.C. }\end{array}$ \\
\hline 55003 & El Puig & Alcoi & I.1.2.2. & Anep & Incisa & & 1 & Hombro & $\begin{array}{c}\text { 2/2 s. V-inicios } \\
\text { s. IV a.C. }\end{array}$ \\
\hline 55004 & El Puig & Alcoi & I.1.2.2. & Anep & Incisa & & 1 & Hombro & $\begin{array}{c}2 / 2 \text { s. V-inicios } \\
\text { s. IV a.C. }\end{array}$ \\
\hline 55005 & El Puig & Alcoi & I.1.2. & Anep & Incisa & & 1 & Hombro & $\begin{array}{c}2 / 2 \text { s. V-inicios } \\
\text { s. IV a.C. }\end{array}$ \\
\hline 62001 & Illeta dels Banyets & El Campello & I.1.2. & Anep & Incisa & & 1 & Hombro & Ss. V-IV a.C. \\
\hline 62002 & Illeta dels Banyets & El Campello & I.1.2. & Anep & Incisa & & 1 & Hombro & Ss. V-IV a. C. \\
\hline 97001 & Illeta dels Banyets & El Campello & I.1. & Anep & Impresa & B-II & 1 & Galbo? & Ss. V-III a.C. \\
\hline 97002 & Illeta dels Banyets & El Campello & I.1.2. & Anep & Incisa & & 1 & Hombro & Ss. V-III a.C. \\
\hline 67001 & La Picola & Santa Pola & I.1. & Epi & Incisa/Esgrafiada & & 1 & Galbo & Ss. V-IV a.C. \\
\hline 67002 & La Picola & Santa Pola & I.1.2. & Anep & Incisa/Esgrafiada & & 1 & Tercio sup. & Ss. V-IV a.C. \\
\hline 71001 & Alt de Benimaquia & Dénia & I.1.1. & Anep & Incisa & & 1 & Hombro & $\begin{array}{l}\text { Fin. s. VII-VI } \\
\text { a.C. }\end{array}$ \\
\hline 108001 & Colmenares & Alacant & I.1.2. & Anep & Incisa & & 1 & Hombro & S. IV a.C. \\
\hline 108002 & Colmenares & Alacant & I.1.2. & Anep & Incisa & & 1 & Hombro & S. IV a.C. \\
\hline 108003 & Colmenares & Alacant & I.1. & Anep & Incisa & & 1 & Hombro & S. IV a.C. \\
\hline 109001 & $\begin{array}{c}\text { Lucentum/Tossal de } \\
\text { Manises } \\
\end{array}$ & Alacant & I.1.2. & Anep & Incisa & & 1 & Hombro & Ss. IV-III a.C. \\
\hline 109002 & $\begin{array}{c}\text { Lucentum/Tossal de } \\
\text { Manises } \\
\end{array}$ & Alacant & I.1.2.3. & Anep & Incisa & & 1 & Hombro & Ss. IV-III a.C. \\
\hline 111001 & Tossal de les Basses & Alacant & I.1.2.3. & Anep & Incisa & & 1 & Hombro & S. IV a.C. \\
\hline 111002 & Tossal de les Basses & Alacant & I.1.2.4. & Anep & Incisa & & 1 & Hombro & S. IV a.C. \\
\hline 111003 & Tossal de les Basses & Alacant & I.1.2.2. & Anep & Incisa & & 1 & Hombro & S. IV a.C. \\
\hline 112001 & Benimassot & Benimassot & I.1.2. & Anep & Incisa & & 1 & Hombro & S. IV a.C. \\
\hline 116001 & Tossal de les Basses & Alacant & I.1.2. & Anep & Incisa & & 1 & Hombro & S. IV a.C \\
\hline 16018 & Kelin & $\begin{array}{c}\text { Caudete de las } \\
\text { Fuentes }\end{array}$ & I.1.2. & Anep & Impresa & B-I & 1 & Asa & $\begin{array}{l}\text { S. III-1/4 s. II } \\
\text { a.C. }\end{array}$ \\
\hline
\end{tabular}




\begin{tabular}{|c|c|c|c|c|c|c|c|c|c|}
\hline Num & Yacimiento & Municipio & Forma & Clase & Técnica & Tipo & Cantidad & Ubicación & Cronología \\
\hline 16019 & Kelin & $\begin{array}{l}\text { Caudete de las } \\
\text { Fuentes }\end{array}$ & I.1. & Anep & Incisa & & 1 & Asa & $\begin{array}{l}\text { S. III-1/4 s. II } \\
\text { a.C. }\end{array}$ \\
\hline 16020 & Kelin & $\begin{array}{l}\text { Caudete de las } \\
\text { Fuentes }\end{array}$ & I.1. & Anep & Incisa & & 1 & Asa & $\begin{array}{l}\text { S. III- } 1 / 4 \text { s. II } \\
\text { a.C. }\end{array}$ \\
\hline 17005 & Casillas del Cura & Venta del Moro & I.1 & Anep & Impresa & B-III & 1 & Asa & Ss. V-IV a.C. \\
\hline 58001 & Covarrobles & Fuenterrobles & I.1. & Anep & Impresa & B-II & 1 & Asa & Ss. IV-III a.C. \\
\hline 59001 & P.U.R.-2 & $\begin{array}{l}\text { Villargordo del } \\
\text { Cabriel }\end{array}$ & I.1. & Anep & Incisa & & 1 & Asa & Ss. IV-III a.C. \\
\hline 64001 & $\begin{array}{c}\text { La Bastida de les } \\
\text { Alcusses }\end{array}$ & Moixent & I.1. & Anep & Impresa & B-I & 1 & Asa & S. IV a.C. \\
\hline 64002 & $\begin{array}{c}\text { La Bastida de les } \\
\text { Alcusses }\end{array}$ & Moixent & I.1. & Anep & Impresa & B-I & 1 & Asa & S. IV a.C. \\
\hline 70001 & La Atalaya & $\begin{array}{l}\text { Caudete de las } \\
\text { Fuentes }\end{array}$ & I.1. & Anep & Impresa & B-I & 1 & Asa & $\begin{array}{l}\text { S. III- } 1 / 4 \text { s. II } \\
\text { a.C. }\end{array}$ \\
\hline 74001 & Tos Pelat & Moncada & I.1. & Anep & Incisa & & 1 & Asa & Ss. V-IV a.C. \\
\hline 78001 & Los Terreros & Torrebaja & I.1. & Epi & Esgrafiada & & 1 & Asa & Ss. VI-II a.C. \\
\hline 80001 & Rambla de la Alcantarilla & Requena & I.1. & Anep & Impresa & B-I & 2 & Asa & Ss. V-III a.C. \\
\hline 82001 & Casa de la Alcantarilla & Requena & I.1. & Anep & Impresa & A-I & 1 & Asa & Ss. VI-I a.C. \\
\hline 87001 & La Tejería & Fuenterrobles & I.1. & Anep & Impresa & B-II & 1 & Asa & Ss. II-I a.C. \\
\hline 89001 & El Zoquete & Requena & I.1. & Anep & Impresa & $\mathrm{B}$ & 1 & Asa & Ss. V-III a.C. \\
\hline 90001 & Saiti & Xàtiva & I.1.2. & Anep & Impresa & B-II & 2 & Hombro & Ss. V-I a.C. \\
\hline 79001 & $\begin{array}{l}\text { Camino de las Casas del } \\
\text { Rincón del Ramo }\end{array}$ & Iniesta & I.1. & Anep & Impresa & B-VII & 1 & Asa & Ss. IV-III a.C. \\
\hline 92001 & Cala Sant Vicenç & Pollença & I.1. & Anep & Incisa & & 1 & Tercio sup. & 520-500 a.C. \\
\hline 114001 & Puig sa Morisca & Calvià & I.1.2.4. & Anep & Incisa & & 1 & Hombro & S. IV a.C \\
\hline 23023 & Binisafúller & Sant Lluís & \begin{tabular}{|l|} 
I.1. \\
\end{tabular} & Anep & Incisa & & 1 & Galbo & 2/4 s. IV a.C. \\
\hline 23024 & Binisafúller & Sant Lluís & I.1. & Anep & Incisa & & 1 & Galbo & 2/4 s. IV a.C. \\
\hline 23025 & Binisafúller & Sant Lluís & I.1. & Anep & Incisa & & 1 & Galbo & 2/4 s. IV a.C. \\
\hline 23026 & Binisafúller & Sant Lluís & I.1. & Anep & Incisa & & 1 & Galbo & 2/4 s. IV a.C. \\
\hline 23027 & Binisafúller & Sant Lluís & I.1. & Anep & Incisa & & 1 & Galbo & 2/4 s. IV a.C. \\
\hline 23028 & Binisafúller & Sant Lluís & I.1. & Epi & Incisa & & 1 & Galbo & 2/4 s. IV a.C. \\
\hline 23029 & Binisafúller & Sant Lluís & I.1. & Epi & Incisa & & 1 & Tercio inf. & 2/4 s. IV a.C. \\
\hline 23030 & Binisafúller & Sant Lluís & I.1. & Epi & Incisa & & 1 & Galbo & 2/4 s. IV a.C. \\
\hline 23031 & Binisafúller & Sant Lluís & I.1. & Epi & Incisa & & 1 & Galbo & 2/4 s. IV a.C. \\
\hline 23032 & Binisafúller & Sant Lluís & I.1.2.1. & Anep & Incisa & & 1 & Hombro & 2/4 s. IV a.C. \\
\hline 23033 & Binisafúller & Sant Lluís & I.1.2. & Anep & Incisa & & 1 & Hombro & 2/4 s. IV a.C. \\
\hline 69001 & Son Catlar & Ciutadella & I.1. & Anep & Impresa & B-II & 1 & Hombro & Ss. IV-II a.C. \\
\hline 113001 & Cales Coves & Alaior & I.1.2. & Anep & Incisa & & 1 & Hombro & Ss. IV-II a.C. \\
\hline 24002 & Alorda Park & Calafell & I.1.2. & Anep & Impresa & B-II & 1 & Hombro & S. III a.C. \\
\hline 24003 & Alorda Park & Calafell & I.1.2. & Anep & Pintada & & 1 & Hombro & S. IV a.C. \\
\hline 24004 & Alorda Park & Calafell & I.1. & Anep & Pintada & & 1 & Galbo & S. IV a.C. \\
\hline 24005 & Alorda Park & Calafell & I.1.2. & Anep & Pintada & & 1 & Asa & S. IV a.C. \\
\hline 24006 & Alorda Park & Calafell & I.1. & Epi & Esgrafiada & & 1 & Galbo & S. IV a.C \\
\hline 24007 & Alorda Park & Calafell & I.1. & Anep & Impresa & $\mathrm{B}$ & 1 & Asa & S. III-II a.C. \\
\hline 60001 & Castellet de Banyoles & Tivissa & I.1. & Epi & Incisa/Esgrafiada & & 1 & Asa & S. III a.C. \\
\hline 61001 & $\begin{array}{l}\text { Tossal del Moro de } \\
\text { Pinyeres }\end{array}$ & Batea & I.1. & Anep & Impresa & B-II & 1 & Asa & 2/2 s. V a.C. \\
\hline 83001 & Sant Miquel & Vinebre & I.1. & Epi & Incisa & & 1 & Borde & Ss. II-I a.C. \\
\hline 83002 & Sant Miquel & Vinebre & I.1. & Epi & Incisa/Esgrafiada & & 1 & Galbo & Ss. II-I a.C. \\
\hline 84001 & El Vilar & Valls & I.1. & Anep & Impresa & B-VII & 1 & Asa & Ss. III-II a.C. \\
\hline 84002 & El Vilar & Valls & I.1.2. & Anep & Impresa & B-II & 1 & Asa & $\begin{array}{l}\text { S. IV-1/4 s. II } \\
\text { a.C. }\end{array}$ \\
\hline 84003 & El Vilar & Valls & I.1.2. & Anep & Impresa & B-II & 1 & Asa & $\begin{array}{l}\text { S. IV-1/4 s. II } \\
\text { a.C. }\end{array}$ \\
\hline 84004 & El Vilar & Valls & I.1.2. & Anep & Impresa & B-I & 1 & Asa & $\begin{array}{l}\text { S. IV- } 1 / 4 \text { s. II } \\
\text { a.C. }\end{array}$ \\
\hline 84005 & El Vilar & Valls & I.1.2. & Anep & Impresa & B-I & 1 & Asa & $\begin{array}{l}\text { S. IV-1/4 s. II } \\
\text { a.C. }\end{array}$ \\
\hline 84006 & El Vilar & Valls & I.1. & Epi & Pintada & & 1 & Tercio sup. & $\begin{array}{l}\text { Fin. S. III- } 1 / 4 \mathrm{~s} \text {. } \\
\text { II a.C. }\end{array}$ \\
\hline 84007 & El Vilar & Valls & I.1. & Anep & Pintada & & 1 & Tercio sup. & $\begin{array}{l}\text { Fin. S. III- } 1 / 4 \mathrm{~s} \text {. } \\
\text { II a.C. }\end{array}$ \\
\hline
\end{tabular}




\begin{tabular}{|c|c|c|c|c|c|c|c|c|c|}
\hline Num & Yacimiento & Municipio & Forma & Clase & Técnica & Tipo & Cantidad & Ubicación & Cronología \\
\hline 84008 & El Vilar & Valls & I.1. & Anep & Pintada & & 1 & Tercio sup. & $\begin{array}{l}\text { Fin. S. III-1/4 s. } \\
\text { II a.C. }\end{array}$ \\
\hline 91001 & Fontscaldes & Valls & I.1. & Anep & Pintada & & 1 & Tercio sup. & 2/4-3/4 s. II a.C. \\
\hline 91002 & Fontscaldes & Valls & I.1.2. & Epi & Pintada & & 1 & Hombro & $\begin{array}{c}\text { Fin. s. III-inicios } \\
\text { I a.C. }\end{array}$ \\
\hline 29002 & Turó de Ca n’Olivé & $\begin{array}{l}\text { Cerdanyola del } \\
\text { Vallès }\end{array}$ & I.1.2. & Epi & Esgrafiada & & 1 & Hombro & 1/2 s. III a.C \\
\hline 29003 & Turó de Ca n'Olivé & $\begin{array}{l}\text { Cerdanyola del } \\
\text { Vallès }\end{array}$ & I.1. & Epi & Esgrafiada & & 1 & Galbo & Ss. II-I a. C. \\
\hline 30006 & Camí de Vista Alegre & Mataró & I.1.2. & Anep & Incisa & & 1 & Hombro & 1/2 s. III a.C. \\
\hline 75001 & Can Vilà & Premià de Dalt & I.1. & Epi & Incisa & & 1 & Galbo & Ss. II-I a.C. \\
\hline 75002 & Can Vilà & Premià de Dalt & I.1. & Anep & Impresa & B-I & 5 & Borde & Ss. II-I a.C. \\
\hline 94001 & Olèrdola & Olèrdola & I.1.2. & Anep & Impresa & B-II & 2 & Hombro & 2/4 s. I a.C. \\
\hline 94002 & Olèrdola & Olèrdola & I.1. & Anep & Impresa & B-II & 1 & Asa & Ss. II-I a.C. \\
\hline 94003 & Olèrdola & Olèrdola & I.1. & Anep & Impresa & B-II & 1 & Asa & Ss. II-I a.C. \\
\hline 94004 & Olèrdola & Olèrdola & I.1. & Anep & Incisa & & 1 & Asa & Ss. II-I a.C. \\
\hline 94005 & Olèrdola & Olèrdola & I.1. & Anep & Impresa & $\mathrm{B}$ & 1 & Asa & 1/2 s. II a.C. \\
\hline 94006 & Olèrdola & Olèrdola & I.1. & Anep & Impresa & $\mathrm{B}$ & 1 & Asa & 1/2 s. I a.C. \\
\hline 94007 & Olèrdola & Olèrdola & I.1. & Anep & Impresa & B & 1 & Asa & 1/2 s. I a.C. \\
\hline 94008 & Olèrdola & Olèrdola & I.1. & Anep & Impresa & $\mathrm{B}$ & 1 & Asa & 1/2 s. I a.C. \\
\hline 94009 & Olèrdola & Olèrdola & I.1. & Anep & Impresa & $\mathrm{B}$ & 1 & Asa & 1/2 s. I a.C. \\
\hline 94010 & Olèrdola & Olèrdola & I.1. & Anep & Impresa & $\mathrm{B}$ & 1 & Tercio sup. & 1/2 s. I a.C. \\
\hline 94011 & Olèrdola & Olèrdola & I.1. & Anep & Impresa & $\mathrm{B}$ & 1 & Asa & Ss. II-I a.C. \\
\hline 94012 & Olèrdola & Olèrdola & I.1. & Epi & Incisa & & 1 & Galbo & 2/4 s. I a.C. \\
\hline 94013 & Olèrdola & Olèrdola & I.1.2. & Anep & Pintada & & 1 & Hombro & Fin. s. II a.C. \\
\hline 94014 & Olèrdola & Olèrdola & I.1.2. & Epi & Incisa & & 1 & Hombro & 2/4 s. I a.C. \\
\hline 94015 & Olèrdola & Olèrdola & I.1. & Anep & Incisa & & 1 & Galbo & 2/4 s. I a.C. \\
\hline 94016 & Olèrdola & Olèrdola & I.1. & Anep & Incisa & & 1 & Galbo & 2/4 s. I a.C. \\
\hline 86001 & Tossal de les Tenalles & Sidamon & I.1. & Epi & Incisa & & 1 & Tercio sup. & $\begin{array}{l}\text { Fin. S. III-1/4 s. } \\
\text { II a.C. }\end{array}$ \\
\hline 86002 & Tossal de les Tenalles & Sidamon & I.1.2. & Epi & Incisa/Esgrafiada & & 1 & Asa & $\begin{array}{l}\text { Fin. S. III-1/4 s. } \\
\text { II a.C. }\end{array}$ \\
\hline 86003 & Tossal de les Tenalles & Sidamon & I.1.2. & Anep & Impresa & B-I & 1 & Asa & $\begin{array}{l}\text { Fin. S. III-1/4 s. } \\
\text { II a.C. }\end{array}$ \\
\hline 96001 & La Fogonussa & $\begin{array}{l}\text { Sant Martí de } \\
\text { Riucorb }\end{array}$ & I.1. & Anep & Impresa & B-VIII & 1 & Asa & Ss. IV-II a.C. \\
\hline 96002 & La Fogonussa & $\begin{array}{l}\text { Sant Martí de } \\
\text { Riucorb }\end{array}$ & I.1. & Anep & Impresa & B-VII & 1 & Asa & Ss. IV-II a.C. \\
\hline 96003 & La Fogonussa & $\begin{array}{l}\text { Sant Martí de } \\
\text { Riucorb }\end{array}$ & I.1. & Anep & Impresa & B & 1 & Asa & Ss. IV-II a.C. \\
\hline 96004 & La Fogonussa & $\begin{array}{l}\text { Sant Martí de } \\
\text { Riucorb }\end{array}$ & I.1. & Epi & Incisa & & 1 & Asa & Ss. IV-II a.C. \\
\hline 96005 & La Fogonussa & $\begin{array}{l}\text { Sant Martí de } \\
\text { Riucorb }\end{array}$ & I.1. & Epi & Incisa & & 1 & Asa & Ss. IV-II a.C. \\
\hline 98001 & Molí d'Espígol & Tornabous & I.1. & Epi & Esgrafiada & & 1 & Asa & S. III a.C. \\
\hline 101002 & Iesso & Guissona & I.1. & Epi & Impresa & A & 1 & Asa & Fin. s. I a.C. \\
\hline 73013 & Contrebia Belaisca & Botorrita & I.1.2. & Epi & Esgrafiada & & 1 & Galbo & Ss. II-I a.C. \\
\hline 45005 & Puig de Sant Andreu & Ullastret & I.1. & Anep & Impresa & B-I & 1 & Asa & S. III a.C. \\
\hline 45006 & Puig de Sant Andreu & Ullastret & I.1.2.5. & Anep & Incisa & & 1 & Hombro & 1/2 s. IV a.C. \\
\hline 45007 & Puig de Sant Andreu & Ullastret & I.1.2.5. & Anep & Incisa & & 1 & Hombro & 1/2 s. IV a.C. \\
\hline 45008 & Puig de Sant Andreu & Ullastret & I.1.2.5. & Anep & Incisa & & 1 & Hombro & $1 / 2$ s. IV a.C \\
\hline 45009 & Puig de Sant Andreu & Ullastret & I.1.2.5. & Anep & Incisa & & 1 & Hombro & S. IV a.C \\
\hline 46002 & Illa d'En Reixac & Ullastret & I.1. & Epi & Incisa & & 1 & Asa & 2/2 s. IV a.C. \\
\hline 93001 & Rhode & Roses & I.1.2. & Anep & Impresa & B-II & 1 & Asa & Ss. III-II a.C. \\
\hline 100001 & $\begin{array}{c}\text { Camp d'En Gou-Gorg } \\
\text { d'En Batlle }\end{array}$ & Ullastret & I.1. & Anep & Impresa & B-II & 1 & Asa & 2/2 s. III a.C. \\
\hline 104001 & Montbarbat & Lloret de Mar & I.1. & Anep & Incisa/Esgrafiada & & 1 & Asa & Ss. IV-III a.C. \\
\hline 68001 & Lattara & Lattes & I.1.2. & Epi & Incisa/Esgrafiada & & 1 & Tercio sup. & 300/ 100 a.C. \\
\hline 95011 & Pech Maho & Sigean & I.1. & Epi & Esgrafiada & & 1 & Hombro & 510-450 a.C. \\
\hline
\end{tabular}


Profa. Dra.Lucía Soria Combadiera Facultad de Humanidades Universidad de Castilla-La Mancha Pza. Universidad s/n 02071 Albacete Lucia.soria@uclm.es

Profa. Dra. Consuelo Mata Parreño Dept. Prehistòria i Arqueologia Universitat de València

Av. Blasco Ibáñez 28 46010 València

Consuelo.mata@uv.es

\section{BIBLIOGRAFÍA}

AGUELO, X. y PONS, O., 2011: «El pecio de Binissafúller. Resultados de la campaña 2011», Actas de las Jornadas de ARQUA, 96-101, Cartagena.

AGUELO, X., PONS, O., DE JUAN, C., RAMON, J., MATA, C., SORIA, L., PIQUÉ, R. y ANTOLÍN, F., 2014: «El pecio de Binissafúller. Estado de las investigaciones», I Congreso de Arqueología náutica y subacuática española (Cartagena, 2013), 67-85.

ÁLVAREZ, N., 1997: «El almacén del templo A: aproximación a espacios constructivos especializados y su significación socio-económica», en M. Olcina (ed.), La Illeta dels Banyets (El Campello, Alicante). Estudios de la Edad del Bronce y Época Ibérica, MARQ, Serie Mayor I, 133-174, Alicante.

ÁLVAREZ, N., 1998: «Producción de ánforas contestanas: el Almacén de El Campello (Alicante)», Cypsela, 12, 213-222.

ÁLVAREZ, N., CASTELLÓ, J.S. y GÓMEZ BELLARD, C., 2000: «Estudio preliminar de las ánforas del Alt de Benimaquía (Dénia, Alicante)», Quaderns de Prehistoria i Arqueologia de Castelló, 21, 121-136.

ARTEAGA, O., PADRÓ, J. y SANMARTÍ, E., 1990: El poblado ibérico del Tossal del Moro de Pinyeres (Batea, Terra Alta, Tarragona), Monografies Arqueològiques 7 , Barcelona.

BADIE, A., GAILLEDRAT, E., MORET, P., ROUILLARD, P., SÁNCHEZ, M.J. y SILLIÈRES, P., 2000: Le site antique de La Picola à Santa Pola (Alicante, Espagne), Madrid.

BARBERÁ, J., 1964-1965: «La cerámica barnizada de negro del poblado Ilergeta del Tossal de les Tenalles de Sidamunt (Lérida)», Ampurias, XXVI-XXVII, 135-163.

BELÉN, M., 2006: «Ánforas de los siglos VI-IV a.C. en Turdetania», SPAL, 15, 217-246.

BELÉN, M., ANGLADA, R., ESCACENA J.L., JIMÉNEZ, A., LINEROS, R. y RODRÍGUEZ, I., 1997: Arqueología en Carmona (Sevilla). Excavaciones en la casapalacio del Marqués de Saltillo, Sevilla.

BELTRÁN, M., 2005: «Contrebia Belaisca (Botorrita, Zaragoza)», en A. Jimeno (ed.), Celtíberos. Tras la estela de Numancia, Salamanca.

BLANC-BIJON, V., CARRE, M. B., HESNARD, A. y TCHERNIA, A., 1998: Recueil de timbres sur amphores romaines II (1989-1990 et compléments 1987-1988), Travaux du Centre Camille Jullian 20, Aix-en-Provence. BONET, H. y VIVES-FERRÁNDIZ, J. (eds.), 2011: La Bastida de les Alcusses. 1928-2010, Valencia.

BURRIEL, J. y MATA, C., 2008: «El poblat iber d'El Tòs Pelat (Moncada-Bètera). Un oppidum edetà en l'Horta Nord de València», Quaderns dels Museus Municipals de València, 2, 11-22.

BURRIEL, J. y MATA, C., 2013: «L'oppidum ibèric d'el Tòs Pelat de Moncada (L'Horta Nord, València)», Monte Catano, 14, 75-97.

CALLENDER, M. H., 1970: Roman Amphorae with index of stamps, Oxford.

CARRASCO, G. y VELAZA, J., 2011: «Esgrafiados ibéricos de Alarcos (Ciudad Real)», Palaeohispánica, 11, 225-230.

CARRE, M. B., GAGGADIS-ROLIN, V., HESNARD, A. y TCHERNIA, A., 1995: Recueil de timbres sur amphores romaines (1987- 1988), Travaux du Centre Camille Jullian 16, Aix-en-Provence.

COLL, R., PREVOSTI, M., CAZORLA, F. y MONTLLÓ, J., 2002: «Can Vilá (Premiá de Dalt, El Maresme): un yacimiento ibérico de llanura con producción cerámica, posteriormente romanizado», Laietania, 13, 69-106.

CURA, M., 2006: El jaciment del Moli d'Espígol (Tornabous-Urgell). Excavacions arqueològiques 1987-1992, Monografies 7, Barcelona.

DE HOZ, J., 2009: «Los grafitos y las marcas», en X. Nieto y M. Santos (eds.), El vaixell grec arcaic de Cala Sant Vicenç, Monografies del CASC 7, 153-162, Barcelona.

DESY, P., 1989: Les timbres amphoriques de l'Apulie républicaine. Documents pour une histoire économique et sociale, B.A.R., I.S. 554, Oxford.

DÍAZ, M.A. y JORDÁN, C.B., 2001: «Grafitos procedentes de Contrebia Belaisca», Palaeohispánica, 1, 301-333.

FABRA, M. E. y VILALTA, E., 2008: «El poblat ibèric del Vilar: Cultura material», en J.M. Vergès y J. López (eds.), Valls y la seva historia (II). Prehistòria i Història Antiga, 185-202, Valls.

FABRA, M.E., BURGUETE, S. y VILALTA, E., 2013: «Grafits apareguts al jaciment ibèric del Vilar i als testers de Fontscaldes (Valls, Tarragona). La tènica del carbò vegetal», Saguntum-PLAV, 45, 247-250. Doi: 10.7203/ SAGVNTVM.45.2594

FERRER, J., 2010: «El sistema dual de l'escriptura ibèrica sud-oriental», Veleia, 27, 69-113.

FRANCÈS, J., VELAZA, J. y MONCUNILL, N., 2008: «Los esgrafiados sobre cerámica de Ca n'Oliver (Cerdanyola del Vallès)», Palaeohispánica, 8, 217-242.

FUMADÓ, I., 2014: «El caballero de El Macalón (Nerpio, Abacete).La emergencia de las aristocracias ibéricas y sus nuevas formas de representación», Cuadernos de Prehistoria de la Universidad Autónoma de Madrid, 40, 81-95.

GAILLEDRAT, E. y ROUILLARD, P., 2003: «Pech Maho aux VIe-Ve s. av. J.- C. Une place d'échanges en territoire élisyque», en M. Bats et alii (eds.), Peuples et territoires en Gaule méditerranéenne, Hommage à Guy 
Barruol, Revue Archéologique de Narbonnaise, Supplément 35, 401-410, Montpellier.

GAILLEDRAT, E. y SOLIER, Y.(ed.), 2004: L'établissement côtier de Pech Maho (Sigean, Aude) aux VIe-Ve s. av. J.C. (fouilles 1959-1979), Monographies d'Archéologie Méditerranéenne 19, Lattes.

GARCÉS ESTALLÓ, I. y PÉREZ CONILL, J., 2006: «Inscripció ibèrica ante cocturam del Tossal de les Tenalles (Sidamon, Pla d'Urgell)», en A.A. V.V., Arqueologia $i$ arqueòlegs. El poblat ibèric dels Estinclells de Verdú, 55-62, Verdú.

GARCÉS ESTALLÓ, I. y TORRES, M., 2011: «Inscripció ibèrica, grafits i marques amfòriques procedents de la Fogonussa (Sant Martí de Maldà, Riucorb, Urgell)», Sylloge epigraphica Barcinonensis (SEBarc), IX, 39-58.

GARLAN, Y., 1999: Les timbres amphoriques de Thasos. I. Timbres protothasiens et thasiens anciens, XVIII Études Thasiennes, Athènes.

GENERA, M., 2005: « Grafits ibèrics sobre ceràmica. Darreres troballes a l'Ebre», Paleohispanica, 5, 995-1012.

GUERRERO, V.M. y QUINTANA, C., 2000: «Comercio y difusión de ánforas ibéricas en Baleares», Quaderns de Prehistòria i Arqueologia de Castelló, 21, 153-182.

GRAU, I., 2002: La organización del territorio en el área central de la Contestania Ibérica, Alicante.

GRAU, I., BEDMAR, A., CORTELL, E. y CORTÉS, A., 2012: «Los registros antiguos de El Puig d'Alcoi a la luz de la documentación reciente», Recerques del Museu d'Alcoi, 21, 45-60.

GRAU, I. y SEGURA, J.M., 2013: El oppidum ibérico de El Puig d'Alcoi. Asentamiento y paisaje en las montañas de la Contestania, Alcoi.

GUITARD, J., PERA, J. y ROS, J., 2004: «Arqueologia a l'antiga ciutat romana de Iesso (Guissona, Lleida)», Primer Simposi Patrimoni i turismo cultural: arqueología viva de les ciutats de l'Antiguitat, 153-192, Barcelona.

HERNÁNDEZ ALCARAZ, L. y SALA, F., 1996: El Puntal de Salinas. Un hábitat ibérico del siglo IV a.C. en el Alto Vinalopó, Villena.

JUAN, L.C. y BERMÚDEZ, A., 1989: «Hornos de época republicana en Cataluña», Revista de Arqueología, 98, 40-47.

JUAN, R., PONS, O. y JUAN, Q., 1998: Memòria de la campanya juny-setembre de 1995. Poblat de Son Catlar, Ciutadella.

LAWALL, M. L., 2000: «Graffiti, wine selling and the reuse of amphorae in the Athenian Agora, ca. 430 to 400 B.C.», Hesperia, 69, 1, 3-90.

LÓPEZ SEGUÍ, E., 1997: «El alfar ibérico», en M. Olcina (ed.), La Illeta dels Banyets (El Campello, Alicante). Estudios de la Edad del Bronce y Época Ibérica, MARQ, Serie Mayor I, 221-250, Alicante.

LÓPEZ SEGUÍ, E., 2000: «La alfarería ibérica en Alicante. Los alfares de la Illeta dels Banyets, La Alcudia y el Tossal de Manises», Saguntum-Extra, 3, 241-248.

MARTÍN, A., BUXÓ, R., LÓPEZ, J. B. y MATARÓ, M., 1999: Excavacions arqueològiques a l'Illa d'en Reixac (1987-1992), Monografíes d'Ullastret 1, Girona.
MARTÍN, A., PLANA, R., CODINA, F. y GAY, C., 2008: «El jaciment Camp d'en Gou-Gorg d'en Batlle, un barri periurbà de l'oppidum d'Ullastret (Baix Empordà)», Cypsela, 17, 161-183.

MARTÍNEZ CASTRO, A., 2011: «De la colonización agraria tartésico-orientalizante a la nuclearización ibero-turdetana. Aproximación a la Protohistoria en La Carlota», Antiquitas, 23, 119-141.

MARTÍNEZ CASTRO, A. y TRISTELL, F.J., 1999: «Marcas sobre cerámica ibérica procedentes del noroeste de la campiña cordobesa (términos municipales de La Carlota y Córdoba)», Antiquitas, 10, 73-80.

MARTÍNEZ VALLE, A., 2014: «La Solana de las Pilillas y otros testimonios de producción y consumo de vino en la Meseta de Requena-Utiel», Lucentum, XXXIII, 51-72. DOI: 10.14198/LVCENTVM2014.33.04.

MARTÍNEZ VALLE, A., CASTELLANO, J. J., CUARTERO, F., HORTELANO, L. y SÁEZ, A., 2001: «Los hornos ibéricos de Las Casillas del Cura (Venta del Moro, Valencia)», Anejo de la Revista Lucentum 4, 135-150.

MARTÍNEZ VALLE, A. y HORTELANO, L., 2011: «Ánforas vinarias de Casillas del Cura (Venta del Moro) y Solana de las Pilillas (Requena). Caracterización, similitudes y diferencias», Oleana, 26, 71-88.

MATA, C. y SORIA, L., 1997: «Marcas y grafitos sobre contenedores ibéricos», Archivo de Prehistoria Levantina, XXII, 297-374.

MATA, C., MORENO, A., PÉREZ, G., QUIXAL, D. y VIVES-FERRÁNDIZ, J., 2009: «Casas y cosas del campo: hábitat agrícola y estructura social en los territorios de Edeta y Kelin (siglos V-III a.n.E.)», Arqueo Mediterrània, 11, 143-152.

MATA, C., BONET, H., COLLADO, E., FUENTES, M., IZQUIERDO, I., MARLASCA, R., MORENO, A., PASCUAL J.LL., QUESADA, F., QUIXAL, D. RIPOLLÈS, P.P., SANCHIS, A., SORIA, L. y TORMO, C., 2014: Fauna Ibérica. De lo real a lo imaginario (II), Trabajos Varios del SIP 117, València.

MOLINOS, M., CHAPA, T., RUIZ RODRÍGUEZ, A., PEREIRA, J., RÍZQUEZ, C., MADRIGAL, A., ESTEBAN, A., MAYORAL, V. y LLORENTE, M., 1998: El santuario heroico de El Pajarillo. Huelma (Jaén), Jaén.

MOLIST, N. (ed.), 2009: La intervenció al sector 01 del Conjunt Històric d'Olèrdola. De la prehistòria a l'etapa romana (campanyes 1995-2006), Monografías de Olérdola 2, Barcelona.

MORATALLA, J. y SEGURA, G., 2013: «Colmenares (L'Alacantí), un hábitat ibérico de llanura en época plena», Lucentum, 32, 93-114. DOI: 10.14198/ LVCENTVM2013.32.04.

NIETO, X. y SANTOS, M. (eds.), 2008: El vaixell grec arcaic de Cala Sant Vicenç, CASC 7, Barcelona.

OLCINA, M. (ed.), 1997: La illeta dels Banyets (El Campello, Alicante). Estudios de la edad del Bronce y época ibérica, MARQ, Serie Mayor 1, Alicante.

OLCINA, M., GILABERT, A. y TENDERO, E., 2010: «Lectura púnica del Tossal de Manises (Alicante)», Mainake, XXXII (I), 229-249. 
OTIÑA, P. y VERGES, J.M., 2004: «El poblat ibèric del Vilar (Valls, Alt Camp)», Butlleti Arqueològic, 26, 5-22.

PERA I ISERN, J., 2003: «Epigrafia ibérica a la ciutat romana de Iesso (Guissona, la Segarra)», Revista d'Arqueologia de Ponent, 13, 237-255.

PERA I ISERN, J., 2005: «Pervivencia de la lengua ibérica en el siglo I a.C. El ejemplo de la ciudad Romana de Iesso (Guissona, Lleida)», Palaeohispanica, 5, 315-332.

PÉREZ BALLESTER, J., VELASCO, A., BORREDÁ, R., RODRÍGUEZ, J.A., 2007: «Excavaciones arqueológicas en la solana del Castell de Xàtiva. Campaña de 2007», Saguntum-PLAV, 39, 189-192.

PÉREZ BALLESTER, J., VELASCO, A., BORREDÁ, R. y RODRÍGUEZ, J.A., 2008: «Excavaciones arqueológicas en el solar de la antigua Saitabi (la Solana del Castell, Xàtiva). Campaña de 2008», Saguntum-PLAV, 40, 237-242.

PÉREZ BALLESTER, J., VELASCO, A., BORREDÁ, R. y RODRÍGUEZ, J.A., 2011: «La Solana del Castell (Xàtiva). Campaña de 2010», Saguntum-PLAV, 43, 199-203. Doi: 10.7203/SAGVNTVM.43.1659.

PÉREZ BALLESTER, J., VELASCO, A., BORREDÁ, R. y RODRÍGUEZ, J.A., 2013: «Campañas de excavaciones de 2011 y 2012 en la Solana del Castell (Xàtiva)», Saguntum-PLAV, 45, 243-245. Doi: 10.7203/ SAGVNTVM.45.3025.

PÉREZ I CONILL, J.: Tossal de les Tenalles, http://calaix. gencat.cat/bitstream/handle/10687/9450/qmem6857 web.pdf? sequence $=1$

PÉREZ JORDÀ, G., MATA, C., MORENO, A. y QUIXAL, D., 2007: «L'assentament ibèric del Zoquete (Requena, València): resultats preliminars de la $1^{\mathrm{a}}$ campanya d'excavació», Saguntum-PLAV, 39, 185-188.

PÉREZ SUÑÉ, J. M. y REVILLA CALVO, V., 1999: «Sellos ibéricos impresos sobre ánfora», XXIV Congreso Nacional de Arqueología (Cartagena, 1997), vol. 3, 359-366, Murcia.

PÉREZ VERBENA, J., 2004: «Los materiales del yacimiento Ibérico de Los Terreros (ss.VI-II a.C.) (Torrebaja, Valencia)», Saguntum-PLAV, 36, 125-146.

PUIG, A.M., 2006: «Les excavacions al Barri Hel-lenístic», en A.M. Puig y A. Martín (coords.), La colònia grega de Rhode (Roses, Alt Empordà), Sèrie Monogràifica 23 , 139-294, Girona.

PUJOL, A., 1989: La población prerromana del extremo nordeste peninsular: génesis y desarrollo de la cultura ibérica en las comarcas gerundenses, 2 vols., CSIC y Universitat Autonoma de Barcelona, Bellaterra.

PY, M., ADROHER, A. y SÁNCHEZ, C., 2001: Dicocer 2. Corpus de céramiques de l'Âge du fer de Lattes (fouilles 1963-1999), Lattara 14, Lattes.

QUIXAL, D., MORENO, A., MATA, C. y PÉREZ JORDÀ, G., 2008: «L'assentament ibèric del Zoquete (Requena, València)», Saguntum-PLAV, 40, 233-236.

QUIXAL, D., MATA, C., ALBELDA, V. y PÉREZ, A., 2011: «Segunda campaña de excavación en el asentamiento ibérico final de La Casa de la Cabeza (Requena, València)», Saguntum-PLAV, 43, 205-208. Doi: 10.7203/ SAGVNTVM.43.1675

REMESAL, J. (ed.), 2004: Epigrafía anfórica, Instrumenta 17, Barcelona.

RIBERA, A., 1982: Las ánforas prerromanas valencianas. Fenicias, ibéricas y púnicas, Trabajos Varios del SIP 73, València.

RIBERA, A., TSANTINI, E., 2008: «Las ánforas del mundo ibérico», en D. Bernal y A. Ribera (eds.), Cerámicas hispanorromanas. Un estado de la cuestión, 617-634, Cádiz.

RODRÍGUEZ ALMEIDA, E., 1989: Los tituli picti de las ánforas de la Bética. I. Tituli Picti de los Severos y la Ratio fisci, Madrid.

ROSSER, P. (coord.), 2003: El Cerro de las Balsas y El Chinchorro: una aproximación a la arqueología del poblamiento prehistórico e ibérico de la Albufereta de Alicante, LQNT, Monográfico 2, Alicante.

ROSSER, P. y FUENTES, C., 2007: Tossal de les Basses: Seis mil años de historia de Alicante, Alicante.

SANMARTÍ, J., y BRUGUERA, R., 1998: «Les àmfores ibèriques del celler del Puig de Sant Andreu (Ullastret, Baix Empordà)», Cypsela, 12, 183-194.

SANMARTÍ, J., BRUGUERA, R. y MORER, J., 1998: «Les àmfores ibériques a la Catalunya meridional», Quaderns de Prehistòria i Arqueologia de Castelló, 19, 267-289.

SANMARTÍ, J., ASENSIO, D., MIRÓ, M.T. y JORNET, R., 2012: «El Castellet de Banyoles (Tivissa): Una ciudad ibérica en el curso inferior del río Ebro», Archivo Español de Arqueología, 85, 43-63.

SANZ, M., 1979: «Población ibérica del valle del Ebro (III). Aportación al estudio del oppidum ibérico de Sant Miquel de Vinebre», Butlletí Arqueològic Real Societat Arqueològica Tarraconense, 1, 11-42.

SOLÉ, D., 2008: «El forn de la Coma», en J.M. Vergès y J. López (coords.), Història de Valls, II. Prehistòria i Història Antiga, 311-318, Valls.

SORIA, L., 2002: «La estructuración del territorio albacetense durante el ibérico pleno (ss. V-III a.C.). Los grandes asentamientos y su distribución en el espacio», II Congreso de Historia de Albacete, vol. I. Arqueología y Prehistoria, 137-144, Albacete.

SORIA, L. y MATA, C., e. p.: «Hornos, marcas...y más allá», III Congreso Internacional de la SECAH-EX OFFICINA HISPANA (Tarragona 2014).

UROZ, J., POVEDA A. M. y MÁRQUEZ J.C., 2003: «Libisosa. La transformación de un oppidum en colonia romana», Alebus, 13, 221-252.

UROZ, J., POVEDA, A. M., MUÑOZ, F. J. y UROZ RODRÍGUEZ, H., 2007: «El departamento 86: Una taberna del barrio industrial ibérico de Libisosa (Lezuza, Albacete)», en J. M. Millán y C. Rodríguez (coords.), Arqueología de Castilla-La Mancha (Cuenca 2005), $143-$ 170 , Cuenca. 